\title{
Potential Alternative Reuse Pathways for Water Treatment Residuals: Remaining Barriers and Questions-a Review
}

\author{
Tomi Turner $(\mathbb{D} \cdot$ Rebecca Wheeler • Adam Stone • \\ Ian Oliver
}

Received: 24 April 2019/Accepted: 16 August 2019 / Published online: 2 September 2019

(C) The Author(s) 2019

\begin{abstract}
Water treatment residuals (WTRs) are byproducts of the coagulation and flocculation phase of the drinking water treatment process that is employed in the vast majority of water treatment plants globally. Production of WTRs are liable to increase as clean drinking water becomes a standard resource. One of the largest disposal routes of these WTRs was via landfill, and the related disposal costs are a key driver behind the operational cost of the water treatment process. WTRs have many physical and chemical properties that lend them to potential positive reuse routes. Therefore, a large quantity of literature has been published on alternative reuse strategies. Existing or suggested alternative disposal routes for WTRs can be considered to fall within several categories: use as a pollutant and excess nutrient absorbent in soils and waters, bulk land application to agricultural soils, use in construction materials, and reuse through elemental recovery or as a wastewater coagulant. The main concerns and limitations restricting current and future beneficial uses of WTRs are discussed within. This includes those limitations linked to issues that have received much research attention such as perceived risks of undesirable phosphorous immobilisation and aluminium toxicity in soils, as well
\end{abstract}

T. Turner $(\bowtie) \cdot$ I. Oliver

School of Geography, Geology and the Environment, Keele

University, Keele ST5 5BG, UK

e-mail: T.turner@keele.ac.uk

R. Wheeler - A. Stone

4R Group, Control House, A1 Business Park, Knottingley Road, Knottingley WF11 0BU, UK as areas that have received little coverage such as implications for terrestrial ecosystems following land application of WTRs.

Keywords Water treatment residuals · Reuse - Sorption · Alum sludge $\cdot$ Land spreading

\section{Introduction}

To meet the water requirements of a growing population, and with escalating efforts to deliver clean drinking water to the estimated $29 \%$ of the global population that do not currently have access to it (WHO 2017), there is an ever-increasing demand for clean and safe drinking water. In order to supply this increasing demand, raw water must be treated to remove any waterborne microorganisms, excess mineral content and suspended sediment. One of the most common methods employed to remove suspended particles and colloids from raw water is the addition of metal salts to initiate a coagulationflocculation process. However, this process results in the generation of vast quantities (generally between 10 and $30 \mathrm{~mL}$ of WTRs for every litre of water clarified) of a sludge-like waste (or by-product) known as water treatment residuals (WTRs), which require an outlet for their disposal or end use (Dassanayake et al. 2015).

Previous reviews have described some of the potential beneficial uses for WTRs considered up to that time, the most recent of which being in 2011, along with the research that had been conducted into their uses (e.g. Babatunde and Zhao (2007); Ippolito et al. (2011)). 
However, considerable advancements in the testing and application of WTRs have been made in the past 10 years. To illustrate, a search on the Web of Science Core Collection for 'water treatment residual*' OR 'water treatment sludge' for the period 2008-2018 returned $>400$ articles. Recent reviews have focussed on various aspects of the WTR reuse, ranging from use as a sorbent (Ippolito et al. 2011), coagulant recovery (Keeley et al. 2014) and the broader scope of WTR utilisation at international levels (Ahmad et al. 2016; Zhao et al. 2018). Therefore, this review aims to expand on these previous works and to produce a comprehensive picture of the generation of WTRs and possible options for end markets, with a particular focus on options that result in environmentally beneficial use. The barriers to widespread adoption of these applications will be examined, including identification of the main knowledge gaps that maintain the uncertainty and concern surrounding potential environmental impacts.

\section{Production}

Being by-products of the coagulation-flocculation process used to remove suspended and colloidal particulates from drinking water, the composition of WTRs is principally determined by the type of coagulants employed and the constituents of the raw water that is being treated. The most common of these coagulants are aluminium sulphate $\left(\mathrm{Al}_{2}\left(\mathrm{SO}_{4}\right)_{3} \cdot 14 \mathrm{H}_{2} \mathrm{O}\right)$, commonly known as alum, and the iron-based salts ferric chloride $\left(\mathrm{FeCl}_{3}\right)$ and ferric sulphate $\left(\mathrm{Fe}_{2}\left(\mathrm{SO}_{4}\right)_{3} \cdot 9 \mathrm{H}_{2} \mathrm{O}\right)$. When these $\mathrm{Al}$ and $\mathrm{Fe}$ salts are applied as coagulants in the presence of alkaline conditions, their $\mathrm{Al} / \mathrm{Fe}$ ions are hydrolysed to form hydroxide precipitates that remove impurities via co-precipitation, sorption, flocculation and settling (Eqs. 1-3) (Dassanayake et al. 2015). The process involves formation of positively charged complexes that are able to sorb and flocculate negatively charged organic impurities effectively by overcoming their initial repelling characteristics (Fig. 1). Depending on the design of a particular water treatment plant, removal of the impurities then proceeds via simple flocculation and settlement under gravity or via a more active process of filtration.

$$
\begin{aligned}
& \mathrm{Al}_{2}\left(\mathrm{SO}_{4}\right)_{3} \cdot 14 \mathrm{H}_{2} \mathrm{O}+6\left(\mathrm{HCO}_{3}\right)^{-} \rightleftharpoons 2 \mathrm{Al}(\mathrm{OH})_{3} \\
& +6 \mathrm{CO}_{2}+14 \mathrm{H}_{2} \mathrm{O}+3 \mathrm{SO}_{4}^{2-}
\end{aligned}
$$

$$
\begin{aligned}
& \mathrm{Fe}_{2}\left(\mathrm{SO}_{4}\right)_{3} \cdot 9 \mathrm{H}_{2} \mathrm{O}+6\left(\mathrm{HCO}_{3}\right)^{-} \rightleftharpoons 2 \mathrm{Fe}(\mathrm{OH})_{3} \\
& \quad+6 \mathrm{CO}_{2}+9 \mathrm{H}_{2} \mathrm{O}+3 \mathrm{SO}_{4}^{2-} \\
& \mathrm{FeCl}_{3} \cdot 6 \mathrm{H}_{2} \mathrm{O}+3\left(\mathrm{HCO}_{3}\right)^{-} \rightleftharpoons \mathrm{Fe}(\mathrm{OH})_{3}+3 \mathrm{CO}_{2} \\
& \quad+3 \mathrm{Cl}^{-}+6 \mathrm{H}_{2} \mathrm{O}
\end{aligned}
$$

Freshly produced WTRs are in a liquid state with high water content (2-4\% solids) making them expensive to transport and challenging to handle, particularly in the volumes generated by large-scale water treatment plants (i.e. $>1000 \mathrm{t}^{\text {year }^{-1}}$ of liquid WTRs produced); hence, dewatering or thickening processes are commonly employed (Dassanayake et al. 2015). Where space availability permits, common dewatering strategies include the use of drying lagoons or beds (Walsh 2009). Where space is less available, dewatering via centrifugation and/or belt presses is often employed. Generally, after the full mechanical dewatering process (e.g. Fig. 2), the solids content of these WTRs increases to between 17 and 35\% solids (Dassanayake et al. 2015). However, this treatment tends to be a more energy intensive and thus more expensive process, leading to many smaller water treatment works (those without the space for drying lagoons) leaving WTRs in a liquid (2$4 \%$ solids) state. The term 'water treatment residual' is a holistic term that applies both to the material when it contains 2 to $4 \%$ solids as well as when in a dried or partially dried condition. These terms are generally used as such by engineers and waste management companies. However, within the scientific literature, it tends to be the dewatered product only that is most widely referred to as WTRs. This discrepancy in definition highlights some of the uncertainties associated with the use and application of WTRs and with how they are discussed in the literature.

The utilization of coagulants during the water treatment process is very common, e.g. it has been adopted by approximately $70 \%$ of the drinking water treatment works in the USA (Keeley et al. 2014). This widespread use of the approach has led to streamlining for costeffectiveness. For example, dose optimisation has reduced $\mathrm{Al}$ coagulant inputs from $\sim 50 \mathrm{mg} \mathrm{L}^{-1}$ in the 1970 s to concentrations as low as $2-5 \mathrm{mg} \mathrm{L}^{-1}$ today, while modern $\mathrm{Fe}$ coagulant dosages range from 4 to $10 \mathrm{mg} \mathrm{L}^{-1}$. These doses depend on the specific coagulant and the turbidity and $\mathrm{pH}$ of the source water (Keeley et al. 2014; WHO 2017). While the literature on this 


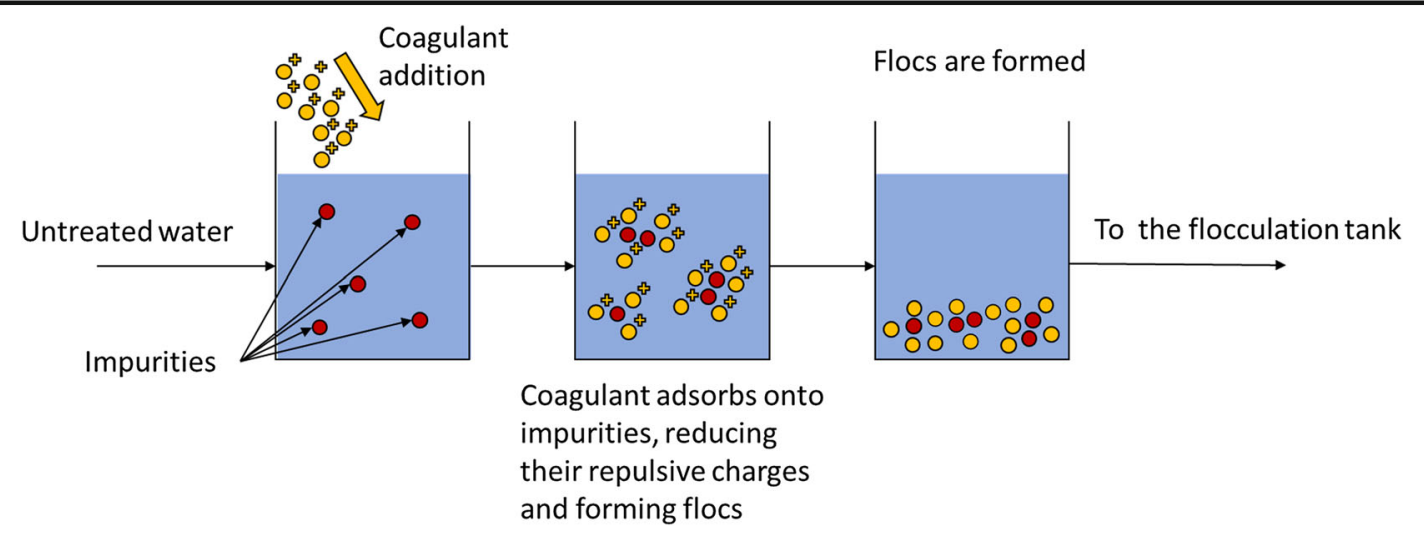

Fig. 1 A simplified diagram of the coagulation process employed during drinking water treatment

topic generally omits or only mentions the addition of further coagulant aids, such as activated silica and organic polyelectrolytes, these also play a key role in aiding the coagulation-flocculation process (Matilainen et al. 2010). As the process has been optimised over time, it is difficult to see any future reductions in the quantities of WTRs produced and thus their generation is only likely to increase with the increasing demand for clean drinking water.

In the UK, for example, 107,000 $t$ and 165,000 $t$ of alum- and ferric-based coagulants are used per annum respectively (Keeley et al. 2014). However, there is limited information available in the form of national production figures for WTRs, with recent estimates only available for their production in a few countries or regions (Fig. 3). Unfortunately, many of these figures are, as previously mentioned, only estimates by government bodies, NGOs or water companies that may not be indicative of the full extent of production. Limited production data may be due to a variety of factors, such as (i) differing practices across treatment plants and regions that result in WTRs of differing water contents that cannot easily be directly compared or summed in terms of total mass, (ii) varying reporting requirements in different regions and countries and (iii) commercial interest issues that encourage resistance in releasing WTR production, disposal and recovery figures. Additionally, production figures rarely discuss the water

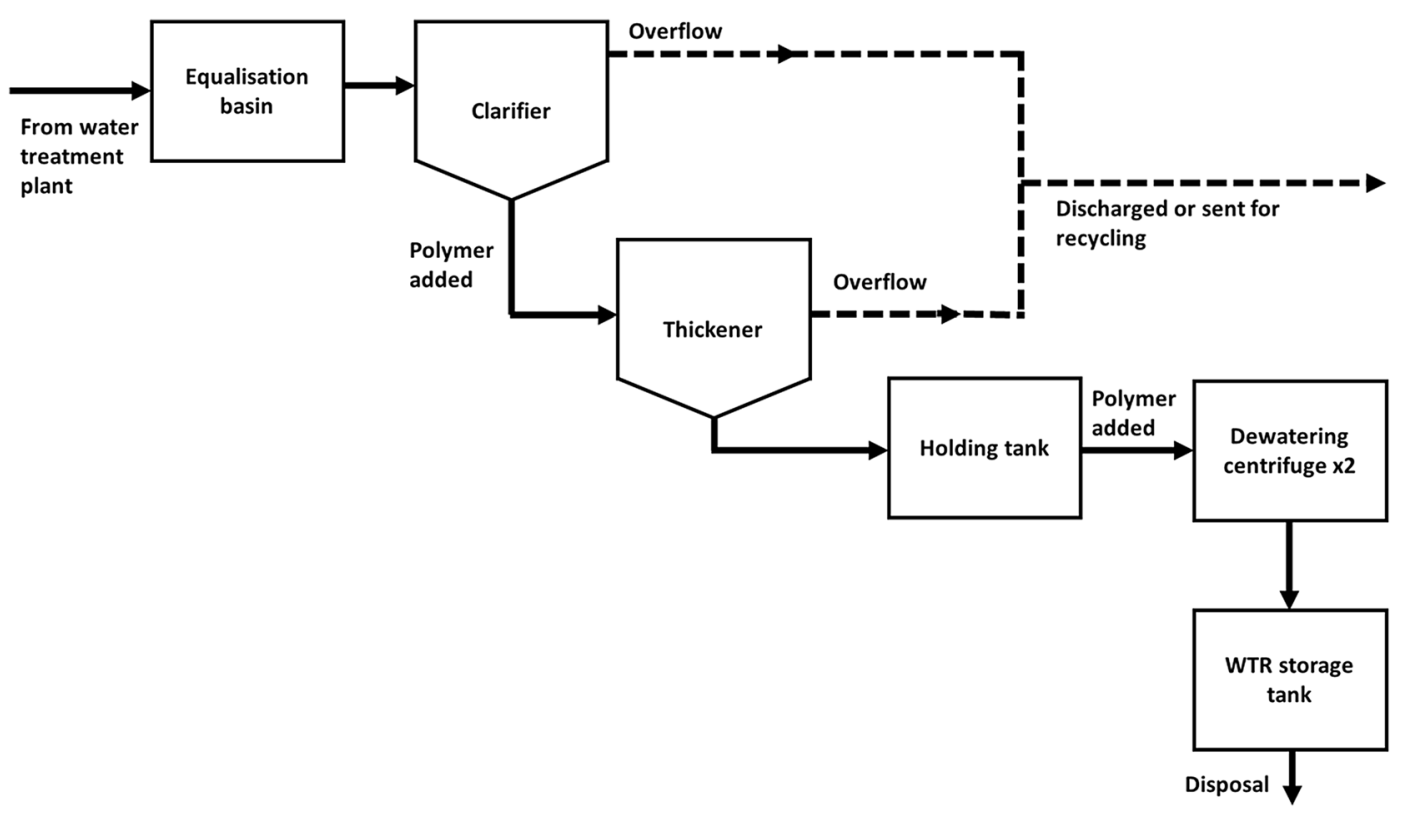

Fig. 2 A typical drying process for treatment residuals (adapted from USEPA (2011)) 
Fig. 3 A selection of publicly available annual, national clean drinking water treatment residual (WTR) production figures in tonnes of dissolved solids, based upon Babatunde and Zhao (2007) and Zhao et al. (2018) and references therein. *figure from 2003 , $* *$ figure from 2013

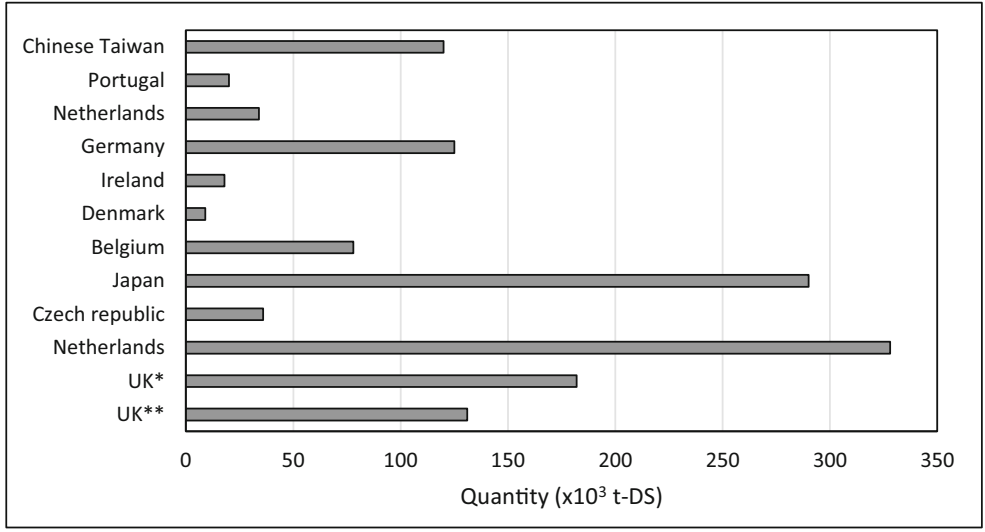

content of the WTRs produced, leaving the weight of solids ambiguous. Nevertheless, some very useful subnational case studies do exist in the literature (Table 1).

These figures highlight the varying amount of waste produced in different regional settings; in the case of Ghaziabad and Noida, where greater quantities of WTRs are produced per litre of water treated (after accounting for water content), a large proportion of WTRs are produced during the monsoon season when the amount of suspended sediment in raw water is higher (Ahmad et al. 2017). This makes estimation of global production volumes of WTRs very difficult. Many past reviews have also referred to a global wet WTR production figure of $10,000 \mathrm{tday}^{-1}$; however, this figure is from the grey literature of the 1990s and the original report (Waite and Dharmappa 1993), and therefore the methods of estimation are no longer readily accessible. However, it is highly likely that global production now exceeds that $10,000 \mathrm{t}^{\text {day }}{ }^{-1}$ estimate.

\section{Physicochemical Properties}

Scanning electron microscope (SEM) studies of WTRs have shown that they have varying particle sizes and are highly porous (Makris et al. 2004a; Ippolito et al. 2011) which, together with the reactive surfaces that $\mathrm{Al}$ and $\mathrm{Fe}$ hydroxides typically have, account for their high sorption capacity. For example, sodium displacement testing revealed WTRs from Oklahoma, USA, to have a high cation-exchange capacity in the order of 13.6 to $56.5 \mathrm{cmol}^{+} \mathrm{kg}^{-1}$, compared to 3.5 to $35.6 \mathrm{cmol}^{+} \mathrm{kg}^{-1}$ for typical soils (Dayton and Basta 2001). Chemical examination of WTRs using X-ray diffusion (XRD)

Table 1 Examples of sub-national water treatment residual production figures

\begin{tabular}{|c|c|c|c|c|c|c|}
\hline $\begin{array}{l}\text { Location of } \\
\text { WTP }\end{array}$ & Coagulant & $\begin{array}{l}\text { Raw water } \\
\text { source }\end{array}$ & $\begin{array}{l}\text { Water treated } \\
\left(\mathrm{Ml} \text { day }^{-1}\right)\end{array}$ & $\begin{array}{l}\text { WTR } \\
\text { production }^{-1} \\
\left(\text { t year }^{-1}\right)\end{array}$ & Water content $\%$ & Reference \\
\hline $\begin{array}{l}\text { Ghaziabad } \\
\text { and Noida, } \\
\text { India }\end{array}$ & $\begin{array}{l}\text { Poly-aluminium } \\
\text { chloride }\end{array}$ & River Ganges & $120 \mathrm{Ml} \mathrm{day}^{-1}$ & $28,100-29,700$ & $2.30-10.65$ & (Ahmad et al. 2017) \\
\hline $\begin{array}{l}\text { Puglia and } \\
\text { Campania, } \\
\text { Italy }\end{array}$ & $\begin{array}{l}\text { Aluminium and } \\
\text { polyvinyl organic } \\
\text { flocculent }\end{array}$ & $\begin{array}{l}\text { Reservoir, } \\
\text { river and } \\
\text { aquifer }\end{array}$ & $950 \mathrm{Ml} \mathrm{day}^{-1}$ & 25,200 & $70-80$ & $\begin{array}{l}\text { (Makris et al. 2004a; } \\
\text { Caniani et al. 2013) }\end{array}$ \\
\hline $\begin{array}{l}\text { Dublin, } \\
\text { County } \\
\text { Kildare }\end{array}$ & Aluminium sulphate & Reservoir & $230 \mathrm{Ml} \mathrm{day}^{-1}$ & $16,400-27,400$ & $72-75$ & $\begin{array}{l}\text { (Yang et al. 2006b; } \\
\text { Babatunde and Zhao } \\
\text { 2010) }\end{array}$ \\
\hline $\begin{array}{l}\text { New York } \\
\text { State, USA }\end{array}$ & Aluminium sulphate & Lake & $190 \mathrm{Ml} \mathrm{day}^{-1}$ & 990 & $\begin{array}{l}\text { Not specified, } \\
\text { calculated total } \\
\text { suspended solids }\end{array}$ & (Gruninger 1975) \\
\hline
\end{tabular}


has revealed that WTRs are amorphous in nature, and therefore lacking a crystalline structure. Nevertheless, the presence of quartz, feldspar, calcite, illite/smectite, feroxyhyte, albite and kaolinite within WTRs has been confirmed (Ippolito et al. 2003; Ippolito et al. 2009b; Ociński et al. 2016b; Ahmad et al. 2018). Further detail on the high sorption capacity of WTRs, which has driven much of the research into beneficial use of the materials, is provided in Section 5.1.

Elemental concentrations, organic matter content and $\mathrm{pH}$ of WTRs can vary greatly depending on the characteristics of raw water treated, coagulant choice and treatment method (Table 2). The total concentration of elements and how readily they leach from WTRs are an important consideration when disposing of or utilising the materials. Elliott et al. (1990) analysed eight $\mathrm{FeCl}_{3}$ and alum-based WTRs from Pennsylvania (USA) and found that the concentrations of $\mathrm{Cd}, \mathrm{Cu}, \mathrm{Cr}, \mathrm{Ni}, \mathrm{Pb}$ and $\mathrm{Zn}$ were all well below the local permissible concentrations for land application. The authors noted that most metals were present in a weakly mobile, non-leachable form (determined by a sequential extraction procedure based on Tessier et al. (1979)). Wang et al. (2014) similarly found that, for six WTRs from various regions in China, the concentrations of $\mathrm{As}, \mathrm{Ba}, \mathrm{Cd}, \mathrm{Cr}$ and $\mathrm{Pb}$ were below the threshold limits of the US Environmental Protection Agency's (USEPA) Toxicity Characteristic Leaching Procedure assessment that is used to determine whether the leachate of a material is hazardous. Example studies in which leachability of elements within WTRs have been assessed using weak salt solutions and weak acids are shown in Table 3. Zhao et al. (2018) considered the possibility that the chemical composition of WTR may have changed through time due to increased environmental contamination (and therefore increased contaminant incorporation during raw water treatment). They found, in the past papers that they reviewed, that a majority of parameters had remained constant between 1990 and 2017 but that there had been a marked increase in $\mathrm{Mn}$, As and Cr in WTRs since the early 2000s. However, the concentration data Zhao and co-workers reviewed was highly variable and so the increase noted for these elements was associated with much uncertainty. The perceived increase reported may also have been influenced by the very limited number of publications available for review that had relevant data pre-2000.

Geotechnical analysis of partially dried but otherwise untreated $(\sim 10-40 \% \mathrm{w} / \mathrm{w}$ dry matter $)$ WTRs established that they have high plasticity, high compressibility and very low permeability (O'Kelly 2008; O'kelly 2010) (Table 4). These characteristics would suggest that untreated WTRs are unsuitable for use in aggregates for engineering; however, some work has been done exploring the use of treated WTRs (i.e. dried, heat treated and ground) in construction (see Section 5.5).

\section{Disposal via Landfill}

Incineration and biological digestion of WTRs are not viable options because of their low combustibility and nutritional value; hence, disposal via landfill remains common. For example, a study from 2006 estimated that $40 \%$ of the dried WTRs produced in the USA were disposed of via landfill while another from 2011 estimated that in Japan the figure was 21\%, and in 1999 it was suggested that $57 \%$ of the WTRs in the UK went to landfill (Keeley et al. 2014). However, more recent data compiled from between 2014 and 2016 by Zhao et al. (2018) paints a more positive picture, estimating that $98 \%, 55 \%$ and $75 \%$ of WTRs are recycled or reused in the Netherlands, Czech Republic and Denmark, respectively. Anecdotal evidence would suggest that it is highly likely that this large proportion of WTRs being recycled also occurs across other European countries. Within Europe, under the European Waste Code

Table 2 Typical components and properties of dry water treatment residuals (WTRs) reported in the literature

\begin{tabular}{llllllllll}
\hline $\begin{array}{l}\mathrm{Al} \\
\left(\mathrm{g} \mathrm{kg}^{-1}\right)\end{array}$ & $\begin{array}{l}\mathrm{Fe} \\
\left(\mathrm{g} \mathrm{kg}^{-1}\right)\end{array}$ & $\begin{array}{l}\mathrm{P} \\
\left(\mathrm{g} \mathrm{kg}^{-1}\right)\end{array}$ & $\begin{array}{l}\mathrm{Ca} \\
\left(\mathrm{g} \mathrm{kg}^{-1}\right)\end{array}$ & $\begin{array}{l}\mathrm{Mn} \\
\left(\mathrm{g} \mathrm{kg}^{-1}\right)\end{array}$ & $\begin{array}{l}\mathrm{Pb} \\
\left(\mathrm{mg} \mathrm{kg}^{-1}\right)\end{array}$ & $\begin{array}{l}\mathrm{Zn} \\
\left(\mathrm{mg} \mathrm{kg}^{-1}\right)\end{array}$ & $\begin{array}{l}\mathrm{Ni} \\
\left(\mathrm{mg} \mathrm{kg}^{-1}\right)\end{array}$ & $\begin{array}{l}\mathrm{Cu} \\
\left(\mathrm{mg} \mathrm{kg}^{-1}\right)\end{array}$ & $\begin{array}{l}\mathrm{Organic} \mathrm{matter} \\
(\%)\end{array}$ \\
\hline $6.7-180$ & $1.1-277$ & $0.2-10$ & $0.18-32$ & $0.4-31.6$ & $2.5-69$ & $0.12-246$ & $10.9-60$ & $35-624$ & $5.8-24.5$ \\
\hline
\end{tabular}

Compiled from Lin and Green (1987), Dayton and Basta (2001), Makris et al. (2004b), Makris et al. (2006), Yang et al. (2006a), AgyinBirikorang and O'Connor (2007), Makris et al. (2007), Agyin-Birikorang and O'Connor (2009), Hovsepyan and Bonzongo (2009), Ippolito et al. (2009b), Lombi et al. (2010), Gibbons and Gagnon (2011), Ippolito et al. (2011), Oliver et al. (2011), Putra and Tanaka (2011), Ulén et al. (2012), Wang et al. (2012b), Castaldi et al. (2014) 
Table 3 Extractability of elements/ions ( $\mathrm{mg} \mathrm{kg}^{-1} \pm$ standard error) in water treatment residuals (WTRs)

\begin{tabular}{|c|c|c|c|c|c|c|c|c|c|c|c|c|c|}
\hline $\begin{array}{l}\text { WTR } \\
\text { type }\end{array}$ & $\mathrm{pH}$ & $\begin{array}{l}\mathrm{Al} \\
\left(\mathrm{mg} \mathrm{kg}^{-1}\right)\end{array}$ & $\mathrm{Fe}$ & As & $\mathrm{Cd}$ & $\mathrm{Co}$ & $\mathrm{Ni}$ & $\mathrm{Pb}$ & $\mathrm{Zn}$ & $\mathrm{PO}_{4}{ }^{3-}$ & $\mathrm{SO}_{4}^{2}$ & $\begin{array}{l}\text { Extraction } \\
\text { method }\end{array}$ & Reference \\
\hline Fe sludge & 8.1 & N/A* & N/A & 0.38 & 0.13 & 0.02 & 0.31 & 0.03 & 4 & $<0.01$ & 730 & $0.01 \mathrm{M} \mathrm{CaCl} 2$ & $\begin{array}{l}\text { Chiang et al. } \\
\text { (2012) }\end{array}$ \\
\hline $\mathrm{Fe}$ & 7.4 & $2.8 \pm 0.2$ & $0.6 \pm 0.1$ & $<1.0$ & $<1.0$ & N/A & N/A & $<1.0$ & $<1.0$ & N/A & N/A & $0.001 \mathrm{M} \mathrm{CaCl}_{2}$ & $\begin{array}{l}\text { Howells et al. } \\
\text { (2018) }\end{array}$ \\
\hline $\mathrm{Al}$ & 7.3 & $4.4 \pm 0.4$ & $<1.0$ & $<1.0$ & $<1.0$ & N/A & N/A & $<1.0$ & $1.4 \pm 0.2$ & N/A & N/A & $0.001 \mathrm{M} \mathrm{CaCl}_{2}$ & $\begin{array}{l}\text { Howells et al. } \\
\text { (2018) }\end{array}$ \\
\hline Al sludge & N/A & 10.3 & N/A & N/A & 0.02 & N/A & N/A & $<0.20$ & N/A & N/A & N/A & $\begin{array}{l}0.5 \mathrm{M} \text { acetic } \\
\text { acid }\end{array}$ & $\begin{array}{l}\text { (Caniani et al. } \\
\text { 2013) }\end{array}$ \\
\hline
\end{tabular}

*Data not available

(2014/955/EU), WTRs and related sludges are classified by the code 190902 in the European Waste Catalogue (European Commission 2014), defined as Preparation of water intended for human consumption or water for industrial use - sludges from water clarification'. Within the sovereignty of individual EU countries, various environmental regulations further govern the disposal or recovery and use of WTRs.

The disposal of WTRs is a large contributing factor to the overall cost of the drinking water treatment process. For instance, the Netherlands reportedly spends $€ 30-40$ million on disposal of WTRs annually, while in the UK the most recent data from 2000 suggests an annual expenditure of $£ 5.5$ million (Babatunde and Zhao 2007). The expenses associated with landfill disposal are set to increase further as legislation and taxation in many countries is becoming increasingly stringent in regard to landfill; e.g. the UK government has increased inert landfill waste fees to $\sim £ 90$ per

Table 4 Geotechnical characteristics of Al WTRs (O'kelly 2010)

\begin{tabular}{ll}
\hline Parameter & Value \\
\hline Liquid limit & $100-550$ \\
Plastic limit \% & $80-250$ \\
Specific gravity of solids & $1.8-2.2$ \\
Total volatile solid \% & $10-60$ \\
Bulk density tonne $\mathrm{m}^{-3}$ & $1.0-1.2$ \\
Dry density tonne $\mathrm{m}^{-3}$ & $0.12-0.36$ \\
Effective cohesion $\mathrm{kPa}^{2}$ & 0 \\
Effective angle of shearing resistance $\left(^{0}\right)$ & $28-44$ \\
\hline
\end{tabular}

tonne in 2018 compared to the 1996 rate of $£ 8$ per tonne (Simpson et al. 2002; Keeley et al. 2014; HM Revenue and Customs 2018). This gives an indication of the scale of increasing costs related to WTR disposal by landfill and identifies a clear economic driver for recycling WTRs for environmentally beneficial uses. Additionally, the European Landfill Directive commits its participating states to reducing the amount of biodegradable municipal waste that goes to landfill by certain dates, and WTRs fall into this category (CEC 1999). However, in some regions, the economic tipping point has not yet been reached. For example, Miyanoshita et al. (2009) conducted an economic evaluation of the disposal of WTRs in Japan and reached the conclusion that, based on their modelling, it was still more economically viable at that time to dispose of WTRs via the sewage system than to dewater and use the WTRs. Similarly, to production estimates, annual figures for WTR disposal/alternative end use and their associated costs are difficult to obtain. Nevertheless, beneficial use of the material, across a range of applications, appears to be growing.

\section{Alternative Disposal and Beneficial Use}

Alternative disposal practices and research into their benefits, limitations and restrictions can be grouped into four broad categories: (i) use in treatment of water or soil to remove or immobilise (manage) contaminants or excess nutrients; (ii) other soil/land-related applications; (iii) as a constituent of construction materials; and lastly, 
(iv) reuse and recycling for the drinking/wastewater treatment process.

\subsection{Sorption of Pollutants or Excess Nutrients from Solution}

The chemical composition, amorphous nature and porosity of WTRs impart them with a relatively large and highly reactive surface area when compared to typical soils (Ippolito et al. 2003; Babatunde and Zhao 2007). Therefore, numerous investigations have been conducted to determine the extent to which WTRs can be exploited to sorb certain potentially harmful elements, or elements in excess of desired concentrations, to reduce impacts on the environment. Initial work with WTRs as a sorbent focussed on the removal of excess phosphorous from solution (Ippolito et al. 2003) but many other elements and chemical compounds have since been the target of investigation, including copper, lead, arsenic and certain pesticides and industrial chemicals (Chiang et al. 2012; Elkhatib and Moharem 2015; Ociński et al. 2016b); the sorption capacities for various elements and compounds reported in the literature are summarised in Table 5.

The sorption capacity of WTRs is a function of particle size, surface area and surface charge (i.e. WTRs with a smaller mean particle size can sorb greater quantities of P (Yang et al. 2006a)). Furthermore, the adsorption of $\mathrm{P}$ and arsenic onto Fe hydroxide surfaces of WTRs was thought to be reasonably described by Eqs. 4 and 5 (Parks et al. 2003). While these equations are useful for describing P and As sorption onto WTRs at a general level, it is generally recognised that there are likely many other additional process involved such as ligand exchange reactions, hydroxide exchange reactions, surface complexation reactions and coprecipitation reactions (Parks et al. 2003; Yang et al. 2006a; Gibbons and Gagnon 2011).

$$
2 \mathrm{Al}-\mathrm{OH}+\mathrm{H}_{2} \mathrm{PO}_{4}^{-} \rightleftharpoons(\mathrm{Al})_{2} \mathrm{HPO}_{4}+\mathrm{H}_{2} \mathrm{O}+\mathrm{OH}^{-}
$$

$\mathrm{Fe}-\mathrm{OH}+\mathrm{H}_{2} \mathrm{AsO}_{4}^{-}+\mathrm{H}^{+} \rightarrow \mathrm{Fe}-\mathrm{H}_{2} \mathrm{AsO}_{4}+\mathrm{H}_{2} \mathrm{O}$

Maqbool et al. (2016) successfully used Al-based WTRs to remove $90 \%$ of the orthophosphorus (the simplest form of inorganic $\mathrm{P}$, i.e. $\mathrm{PO}_{4}{ }^{3-}$ ) and $70-80 \%$ of the condensed phosphorus (a more complex chain of orthophosphate units) from synthetic and municipal wastewater using WTRs, while it has been suggested that alum sludge has a greater tendency for uptake of inorganic P than organic P (Gon Kim et al. 2002). Wang et al. (2016) produced filters using Al-based WTRs as a substrate in a WTR:kaolin:humic acid ratio of 10:7:2. Their tests with synthetic solutions found that an adsorption capacity of $1.31 \mathrm{mg} \mathrm{P} \mathrm{g}^{-1}$ could be achieved and after an initial adsorb-desorb cycle using $0.25 \mathrm{~mol} \mathrm{~L}^{-1} \mathrm{NaOH}, 80.0 \%$ of the $\mathrm{P}$ could then be recovered, though this did reduce to $31.4 \%$ after three more cycles. The uptake of P by WTRs was characterised by Bai et al. (2014) as being proportional to oxalate-extractable $\mathrm{Fe}$ and $\mathrm{Al}$, as well as surface area. It has been found that oxidation state has a negligible effect on P sorption and retention by WTRs; however, $\mathrm{pH}$ has been found to have a significant impact on these factors (Oliver et al. 2011; Maqbool et al. 2016). WTRs can also remove fluoride from aqueous solution in a process which is characterised by a decreasing sorption rate after 5 min (Sujana et al. 1998) presumably due to saturation of the most effective fluoride binding sites.

Potentially toxic element (PTE) adsorption by WTRs is also well documented in the literature (McBride 1995; Hovsepyan and Bonzongo 2009; Zhou and Haynes 2011; Chiang et al. 2012). For example, sorption tests conducted on sediments amended with WTRs found high amounts of $\mathrm{Cd}, \mathrm{Co}, \mathrm{Ni}, \mathrm{Pb}$ and $\mathrm{Zn}$ were removed from solution, performing $240 \%$ better than sediments containing equivalent alternative additions of goethite in multi-contaminant testing (Chiang et al. 2012). One comparative study of PTE binding capacity of Fe WTRs and Al WTRs found that, while both forms sorbed large quantities of the metals, Fe WTRs bound more Zn and $\mathrm{Cd}$ from solution than $\mathrm{Al}$ WTRs did across a $\mathrm{pH}$ range between 4.5 and 7.0 (e.g. $\sim 0.200$ and $\sim 0.100 \mathrm{mmol} \mathrm{g}^{-1}$ of each metal sorbed by Fe and Al WTRs respectively at a $\mathrm{pH}$ of 7.0) when applied at a WTR:solution ratio of 0.1:25 (Silvetti et al. 2015) which is in agreement with unpublished results for $\mathrm{Cd}$ generated in our laboratory (Keele University) (Table 5).

Arsenic removal from water using WTRs has also been widely investigated (Makris et al. 2006; Makris et al. 2008; Kim et al. 2012; Caporale et al. 2013; Elkhatib et al. 2015a; Ociński et al. 2016b). Makris et al. (2006) applied both Fe- and Al-based WTRs separately to solutions containing As(III) and As(V) during batch sorption experiments $\left(15,000 \mathrm{mg} \mathrm{kg}^{-1}\right.$ solution equilibrated for 2 days at a $\mathrm{pH}$ of 5.3-6.3). Their results suggested that Fe WTRs showed a greater 


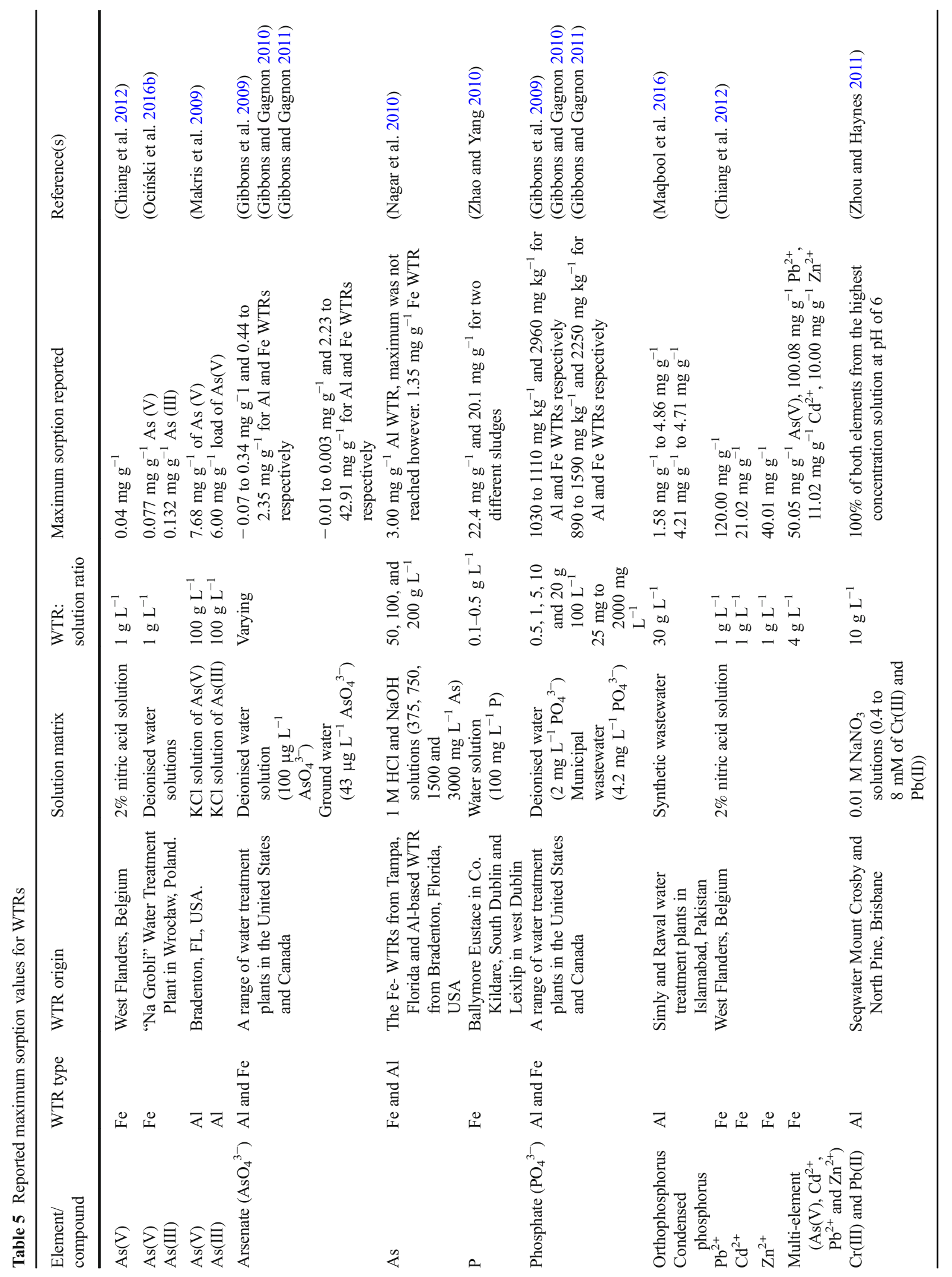


sorption capacity for As(III) than As (V) (99\% As(III) sorbed vs $67 \%$ As(V)), while Al WTRs effectively removed greater quantities of $\mathrm{As}(\mathrm{V})$ than $\mathrm{As}(\mathrm{III})(55 \%$ As(III) vs 93\% As(V)) (Makris et al. 2006). However, Kim et al. (2012) found that Al WTRs adsorbed greater quantities of $\mathrm{As}(\mathrm{III})$ than $\mathrm{As}(\mathrm{V})$, and that $\mathrm{As}(\mathrm{V})$ adsorption rapidly decreases when the $\mathrm{pH}$ increases above 6 . Because of its potential as a low-cost alternative for removing contaminants, and because As contamination of drinking and wastewater is a major environmental and health issue, there have been multiple attempts to calculate the maximum sorption capacities of As and its various forms (i.e. $\mathrm{As}(\mathrm{III})$ and $\mathrm{As}(\mathrm{V})$ ) (Makris et al. 2009; Gibbons and Gagnon 2010; Nagar et al. 2010; Gibbons and Gagnon 2011; Ociński et al. 2016b) (Table 5). Ociński et al. (2016a) incorporated WTRs into an alginate-based polymer in order to reduce the clogging potential of using WTRs in aquatic bed systems, but this resulted in greatly reduced maximum adsorption capacities (3.4 $\mathrm{mg} \mathrm{g}^{-1} \mathrm{As}(\mathrm{III})$ and $\left.2.9 \mathrm{mg} \mathrm{g}^{-1} \mathrm{As}(\mathrm{V})\right)$ which the authors believed was due to impediment by carboxylic groups in polymer chains of the alginate.

The applicability of WTRs for remediating multielement-contaminated storm water has been explored by multiple studies. Soleimanifar et al. (2016) produced encouraging results during batch and column tests by applying WTRs to the surface of mulch, with adsorption rates from synthetic storm water reported as high as $97 \%$ for $\mathrm{Pb}$ (initial concentration, $100 \mathrm{mg} \mathrm{L}^{-1}$ ), $76 \%$ for $\mathrm{Zn}$ (initial concentration $800 \mathrm{mg} \mathrm{L}^{-1}$ ), $81 \%$ for $\mathrm{Cu}$ (initial concentration $100 \mathrm{mg} \mathrm{L}^{-1}$ ) and $97 \%$ for $\mathrm{P}$ (initial concentration $2.30 \mathrm{mg} \mathrm{L}^{-1}$ ) over a 120 -min timeframe. Deng et al. (2016) also produced promising results when using a combination of WTRs and scrap tyre rubber to remove $\mathrm{Cu}$ and $\mathrm{Pb}$ from synthetic stormwater, while limiting the leaching of $\mathrm{Zn}$ from the tyres to some extent. Both of these approaches were employed in order to reduce the clogging that could occur when using solely WTRs.

Treatment of other non-metal and non-nutrient contaminants have also been examined; e.g. Makris et al. (2006) applied Al WTRs to $10 \mathrm{mg} \mathrm{L}^{-1}$ perchlorate solution in a ratio of $1 \mathrm{~g}: 5 \mathrm{~mL}$; reductions in perchlorate of up to $65 \%$ were described over $2 \mathrm{~h}$, increasing to $76 \%$ after $24 \mathrm{~h}$; the authors inferred that the mechanism of removal was the reduction of perchlorate to chloride (Makris et al. 2006). There has been particular success achieved in the application of WTRs to textile industry 
wastewater for the removal of textile dyes (Chu 2001). In one study, around $88 \%$ of a hydrophobic dye (Dianix Blue) was removed from wastewater by additions of $75 \mathrm{mg} \mathrm{L}^{-1}$ of alum at $\mathrm{pH} 9.13$ (Chu 2001), while Vaezi and Batebi (2001) applied ferric sulphate recovered from WTRs to two types of textile industry wastewaters with positive results. More recently, dye removal efficiencies of 53-95\% for alum-based WTRs and 97\% for ferric WTRs have been reported (Moghaddam et al. 2010; Gadekar and Ahammed 2016; Butani and Mane 2017). Following these studies, Yusuff et al. (2017) went a step further and optimised the removal of methylene blue textile dye, achieving a 100\% removal rate by exposing the treatment process to a temperature of $450{ }^{\circ} \mathrm{C}$ and a $\mathrm{pH}$ of 6 . This level of treatment success demonstrates the great potential for environmental benefits that could be gained through this type of WTR application, particularly in developing countries where vast quantities of textiles are produced and wastewater treatment options are often limited (or even absent) because of technical access and cost issues. However, this application of WTRs is not effective for treating wastewater containing hydrophilic dyes due to their high solubility (Chu 2001). Another limitation to this application is the question of further use of WTRs after they have been used to sorb excess dyes and other chemicals in textile-related waste streams; they may be unsuitable for other reuse options and may need to be disposed of via specialist landfill (Asif et al. 2016). Basibuyuk and Kalat (2004) considered the use of WTR sludge for remediating vegetable oil refinery wastewater. Jar experiments revealed that WTRs were as effective as ferric chloride and alum salts. Optimum conditions resulted in the removal of $99 \%$ of the oil and grease, $99 \%$ of total suspended solids and $83 \%$ of the chemical oxygen demand (COD).

Success has also been found in using WTRs to adsorb and immobilise organic pollutants. (2015); Punamiya et al. (2016) successfully removed large quantities of two veterinary antibiotics (tetracycline hydrochloride and oxytetracycline hydrochloride) from solution and immobilised them in manure-treated soils using WTRs. Importantly, in terms of environmental applications, the optimum $\mathrm{pH}$ range for tetracycline sorption was found to be across the range 4.0 to 8.0 , i.e. typical conditions encountered in the natural environment (Punamiya et al. 2015). However, the effectiveness of sorption was reduced in the presence of elevated $\mathrm{P}$, due to competitive ligands. Water treatment residuals have also been shown to be effective in removing cyanobacteria, which are known to contribute to freshwater algal blooms and the production of cyanotoxins, from waterborne cultures, e.g. unicellular and colonial Microcystis aeruginosa, by $89 \%$ and $75 \%$ respectively having had an initial density of 106 cells $\mathrm{mL}^{-1}$ (Wang et al. 2017a).

There have been a handful of studies investigating the application of WTRs that were first milled to $<100$ $\mathrm{nm}$ diameter and thus referred to in the literature as nanoparticle WTRs (nWTRs) (Elkhatib et al. 2015a; Elkhatib et al. 2016; Mahdy et al. 2017). This is done to increase their surface area, and thus their sorption capacity. One study produced a 2- to 3-fold increase in surface area over that of non-milled WTRs (e.g. $129 \mathrm{~m}^{2} \mathrm{~g}^{-1}$ vs $53 \mathrm{~m}^{2} \mathrm{~g}^{-1}$ (Elkhatib et al. 2015b)). Sorption studies have shown that nWTRs have maximum sorption capacities for As, Cd and $\mathrm{P}$ that are greater than those of normal WTRs (e.g. $50 \mathrm{mg} \mathrm{As} \mathrm{g}^{-1}$ compared to $3 \mathrm{mg} \mathrm{g}^{-1}, 47 \mathrm{mg} \mathrm{Cd} \mathrm{g}^{-1}$ compared to $2.80 \mathrm{mg} \mathrm{g}^{-1}$ and $50 \mathrm{mg} \mathrm{P} \mathrm{g}^{-1}$ compared to $1.67 \mathrm{mg} \mathrm{P}$ $\mathrm{g}^{-1}$ ) (Elkhatib and Moharem 2015; Elkhatib et al. 2016). Similar results were produced in another nWTR in batch study experiment, with $\sim 95 \%$ of $\mathrm{P}$ removed from a starting concentration of 5-1000 $\mathrm{mg} \mathrm{P} \mathrm{L}^{-1}$ over a period of $100 \mathrm{~min}$ (Elkhatib et al. 2015b). The study by Elkhatib et al. (2016) also reported the subsequent release of less than $0.2 \%$ of Cd that was initially bound to the WTRs after 4 consecutive desorption cycles. However, although the practicalities, cost implications and long-term effectiveness of milling WTRs to nano-sized particles for use in sorption and water treatment applications are yet to be properly evaluated, it seems very unlikely that this approach would ever become a commercially viable option for mainstream recovery and use of WTRs.

5.2 Use in Constructed Wetlands, Reed Beds and Filter Beds

An area that has received considerable attention in the literature is the use of WTRs as a reactive media in constructed wetlands (CW) or filter beds (Fig. 4). Zhao et al. (2009) reported the results of a long-term (730 days) trial of WTR sludge cake as a reed bed substrate as part of an agricultural wastewater treatment process. Removal efficiencies of $73 \%$ for COD, $83 \%$ biological oxygen demand (BOD), $86 \%$ reactive phosphorus, $89 \%$ soluble $(<0.45-\mu \mathrm{m}$ filtered) reactive 


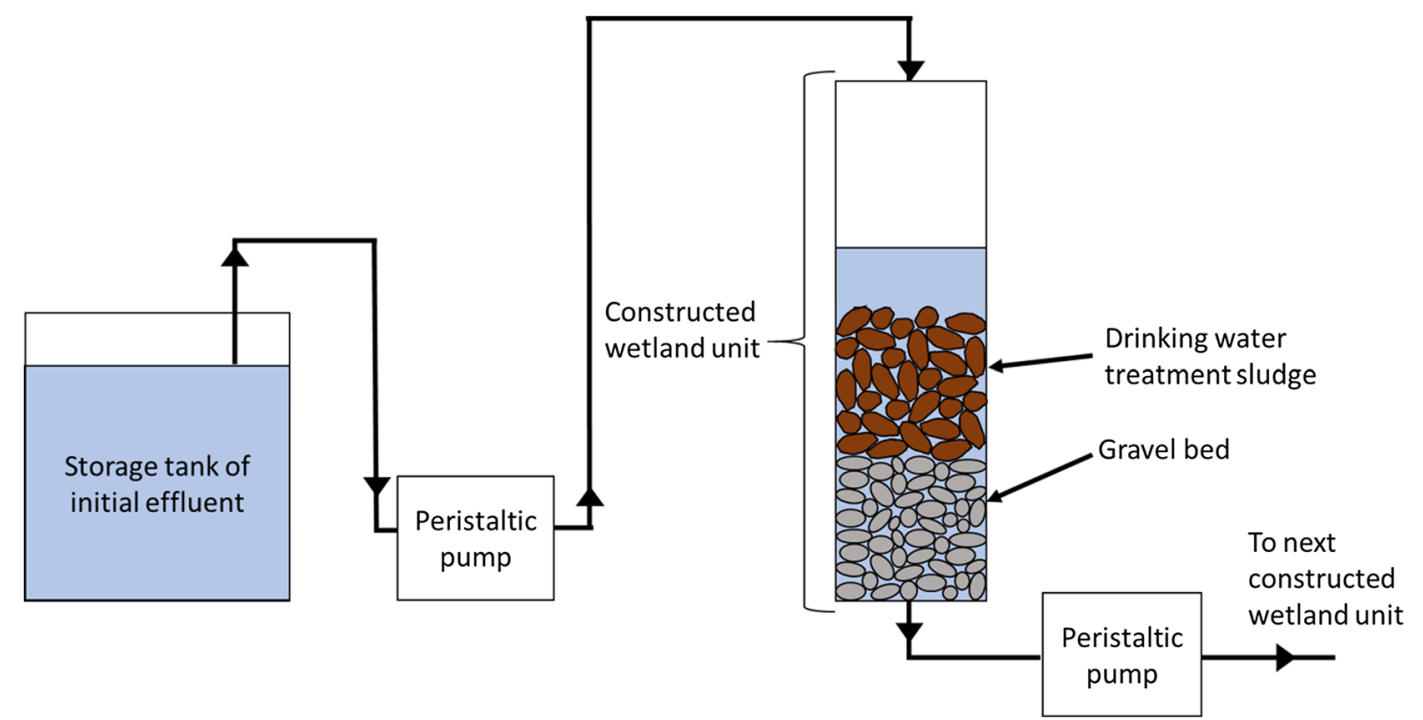

Fig. 4 A generalisation of the WTR constructed wetlands experimental setup, as used in multiple studies (Razali et al. 2007; Babatunde et al. 2009; Babatunde et al. 2010; Zhao et al. 2011)

phosphorus and $78 \%$ suspended solids were achieved. Of this, $42 \%$ of the $\mathrm{P}$ removal was directly related to sorption which is dependent upon the availability of reactive surfaces of WTRs, leading the authors to estimate a working lifetime for WTR-based CWs of 940 years, excluding other limiting factors such as clogging (Zhao et al. 2009). In a follow-up study into the efficiency of COD, BOD, total nitrogen (TN), total phosphorous (TP) and $\mathrm{NH}_{4}-\mathrm{N}$ removal, Zhao et al. (2011) observed monthly reductions of these values in the ranges of $36-84 \%, 57-84 \%, 11-78 \%, 75-94 \%$ and $49-93 \%$ respectively. In another study, Babatunde et al. (2010) reported a reduction of $91 \%$ for BOD and $72 \%$ for COD and a $98 \%$ reduction in soluble reactive $\mathrm{P}$ in a four-stage laboratory-scale constructed wetland which utilized alum WTR as the absorbent medium.

New advances are constantly improving on the existing WTR CW model. For example, Wang et al. (2017b) trialled incorporating Al WTR-based haydites (a heat-expanded aggregate) into wetland cells. This resulted in average removal rates of $90.1 \%, 23.3 \%$, $86.1 \%$, and $97.2 \%$ of COD, $\mathrm{NH}_{4}-\mathrm{N}_{4}, \mathrm{TN}$ and TP respectively. In another study, $\mathrm{Hu}$ et al. (2012) achieved an increased $\mathrm{N}$ removal rate of $83 \%$ under a high nitrogen load (19.1 $\mathrm{g} \mathrm{N} \mathrm{m}^{-2}$ day $^{-1}$ ) by means of a step feeding strategy in a tidal fed WTR CW, compared to 23-59\% in earlier tidal fed WTR-based CWs. More recently, the incorporation of microbial fuel cells into WTR-based CWs has been investigated in several studies (Zhao et al. 2013b; Doherty et al. 2015; Xu et al. 2016a) (Table 6). These systems aim to produce bioelectricity through harnessing microbial breakdown of organic matter, therefore increasing the environmental payoff through energy generation. The reported maximum power outputs for such units are similar to those produced by microbial fuel cells in CWs made from conventional bedding material (i.e. not WTRs) (Zhao et al. 2013b), showing that the use of WTRs incurs no trade-off cost in this regard.

Aluminium WTR CWs have also been incorporated into the aeration tanks of conventional activated sewerage sludge systems, in order to produce green bio-sorption reactors (GBRs) (Liu et al. 2017). Removal rates of $96 \%, 99 \%$ and $90 \%$ for BOD, TP and TN were achieved in a GBR system (Liu et al. 2017). While concerns have arisen that the occurrence of natural organic matter may lead to a deterioration in the $\mathrm{P}$ adsorption rates, this technique still offers a possible pathway for upgrading outdated activated sludge CW systems (Liu et al. 2017).

The largest issue facing WTR CWs over the longterm is clogging, having been reported to occur around 14 months into WTR-based CW's life cycles. However, this can be partially alleviated by the use of an anti-sized gravel bed (i.e. smaller gravel at the base of the bed and larger at the top) and did not occur over a period of 18 months while running a $\mathrm{CW}$ based on the use of 
Table 6 Results from attempts at incorporating microbial fuel cells into WTR-based constructed wetlands (CWs)

\begin{tabular}{|c|c|c|c|c|c|c|}
\hline Type & $\begin{array}{l}\text { Type of } \\
\text { wastewater }\end{array}$ & $\begin{array}{l}\mathrm{COD} \\
\left(\mathrm{mg} \mathrm{L}^{-1}\right)\end{array}$ & $\begin{array}{l}\text { COD removal } \\
(\%)\end{array}$ & $\begin{array}{l}\text { Max power } \\
\left(\mathrm{mW} \mathrm{m} \mathrm{m}^{-2}\right)\end{array}$ & Reference & Notes \\
\hline \multirow[t]{2}{*}{ Vertical upflow } & \multirow[t]{2}{*}{ Swine } & \multirow[t]{2}{*}{1058} & 71.5 & 12.83 & \multirow[t]{2}{*}{ (Zhao et al. 2013b) } & Without aeration \\
\hline & & & 76.5 & 9.4 & & With aeration \\
\hline Simultaneous upflow downflow & Swine & 583 & 64 & 276 & (Doherty et al. 2015) & \\
\hline \multirow[t]{2}{*}{ Vertical upflow } & \multirow[t]{2}{*}{ Swine } & \multirow[t]{2}{*}{484} & 70 & 36.58 & \multirow[t]{2}{*}{ (Xu et al. 2016a) } & Alum cathode \\
\hline & & & 81 & 87.79 & & $\begin{array}{l}10 \% \text { additions of } \\
\text { powder activated } \\
\text { carbon to the cathode }\end{array}$ \\
\hline
\end{tabular}

WTRs in the form of haydites (Zhao et al. 2015; Wang et al. 2017b). In contrast with an earlier study by Oliver et al. (2011) that reported the release of organic matter under anaerobic conditions as a possible cause for concern in relation to water quality effects, Liu et al. (2016) assessed natural organic matter release from a WTRbased $\mathrm{CW}$ and found it to be of low risk to human health. As an additional environmental benefit, once the WTR cakes in CWs have reached the end of their working lifespan, it is possible to recover the $\mathrm{Al}$ and $\mathrm{P}$, in the form of $\mathrm{AlPO}_{4}$, through a process of $\mathrm{P}$ extraction by $\mathrm{H}_{2} \mathrm{SO}_{4}$ addition and $\mathrm{AlPO}_{4}$ precipitation through $\mathrm{pH}$ adjustment (Zhao et al. 2013a). Employing this method resulted in reported recovery rates of $97 \%$ and $99 \%$ for $P$ and $\mathrm{Al}$ respectively (Zhao et al. 2013a). Overall, the use of WTRs in CWs and filter beds is highly promising, particularly with the potential of incorporation of microbial fuel cells. However, the release of certain substances, such as $\mathrm{Al}$ and $\mathrm{Fe}$, under the varying models still requires further research. Further development and trial of anti-clogging techniques would also enhance their efficiency, longevity and likelihood of use.

\subsection{Use in Lakes or Reservoirs}

In addition to application in constructed wetlands and reed beds, use of WTRs as a P sorbing material in lakebeds has also been trialled (Fig. 4). First suggested by Young et al. (1988), multiple recent studies have expanded on this idea (Wang et al. 2012a; Wang et al. 2013a; Takashima et al. 2015; Yuan et al. 2016a). The most common approach is to mix $10 \%$ WTRs by weight with lake sediments (Wang et al. 2012a; Wang et al. 2013a; Yuan et al. 2016b); however, some studies have varied this amount, such as Yuan et al. (2016a). WTRs have the potential to limit internal $\mathrm{P}$ loading within lakes, leading to a reduction in algal growth (Yuan et al. 2016a). This is achieved by preventing $P$ release from sediment, via the sorption and retention mechanisms described in previous sections. However, WTRs have been found to increase overlaying waters Al and Fe concentrations. For example, Wang et al. (2013a) noted that $\mathrm{Fe}$ and $\mathrm{Al}$ concentrations in the overlaying water were marginally increased $\left(<0.03 \mathrm{mg} \mathrm{L}^{-1}\right)$ in all experiments. Furthermore, another study found that $0.0064-0.0073 \mathrm{mg} \mathrm{g}^{-1}$ of Al from WTRs is released into waters when $1 \mathrm{~g}$ was added to $80 \mathrm{~mL}$ of water at its surface and allowed to settle for $2 \mathrm{~h}$ (Wang and Pei 2013). While these increases in overlaying water Fe and $\mathrm{Al}$ concentrations are notable, their impact on ecological receptors will likely be negligible.

Although there are no studies quantifying the P sorption of WTRs when actively deployed in lakes, Phoslock ${ }^{\circledR}$ (bentonite clay containing ion-exchanged La), a commercially available material used in the treatment of excess $\mathrm{P}$ in lakes and which has a similar sorption capacity for $P$ to that of Fe WTRs (i.e. Phoslock 21,670 $\mathrm{mg} \mathrm{P} \mathrm{kg}^{-1}$, Fe WTRs 22,400 $\mathrm{mg} \mathrm{P} \mathrm{kg}^{-1}$ and $20,100 \mathrm{mg} \mathrm{P} \mathrm{kg}^{-1}$ for two different sludges (Zhao and Yang 2010; Meis et al. 2012)), can increase P sorption of a reservoir by $\sim 28 \mathrm{~kg} \mathrm{ha}^{-1}$ when applied at $2.7 \mathrm{~T} \mathrm{ha}^{-1}$ and hence similar levels of performance might be achievable with WTRs. An estimation of the P immobilisation capabilities of WTRs in lake sediments can be expressed by the following Eq. 6 (Wang et al. 2013b).

$\left(\mathrm{Al}_{\mathrm{ox}}+\mathrm{Fe}_{\mathrm{ox}}\right)_{\mathrm{WTR}}=83 \times \mathrm{P}_{m}-40$

where $\left(\mathrm{Al}_{\mathrm{ox}}+\mathrm{Fe}_{\mathrm{ox}}\right)_{\mathrm{WTR}}$ is the sum of oxalateextractable $\mathrm{Al}$ and $\mathrm{Fe}$ content of the WTR and the $\mathrm{P}_{m}$ is the $\mathrm{P}$ concentration in the lake sediments; all terms are 
expressed in moles per gram (Wang et al. 2013b). Therefore, the required volume of WTR for P immobilisation can be estimated if the $\left(\mathrm{Al}_{\mathrm{Ox}}+\mathrm{Fe}_{\mathrm{ox}}\right)_{\mathrm{WTR}}$ and $\mathrm{P}$ concentration in sediments are known.

Yuan et al. (2016b) evaluated the risk of pollution related to WTRs in lake water with regard to environmental regulatory limits and human health risk assessment. WTRs were mixed with sediments $(\sim 10 \%$ WTR by weight) and incubated aerobically and anaerobically in beakers. It was found that, while both $\mathrm{Fe}$ and $\mathrm{Mn}$ exceeded regulatory standards (the Environmental Quality Standard for Surface Water in China, and the National Recommended Water Quality Criteria for fresh water in the USA) after anaerobic incubation, amended sediments were considered to be non-hazardous to aquatic plants.

\subsection{Application to Land}

Land application of WTRs is increasing and may eventually become the most common reuse route. For example, the Sydney Water corporation (New South Wales, Australia) stores and then reuses $100 \%$ of the produced WTRs via land spreading in their catchment area (equating to 5228 dry t during 2011-2012) (Sydney Water 2011). Application of WTRs onto clean (i.e. no previous history of contamination) agricultural and forestry land has become a well-established practice in some regions (e.g. parts of the USA and UK) and has been a topic of periodic research activity (e.g. Bugbee and Frink (1985); Geertsema et al. (1994); Oladeji et al. (2007)). It is difficult to obtain precise figures to support the assertion that land application is growing because of the lack of cohesive data from reliable sources, but there is anecdotal evidence; for example, in the English Midlands and Wales (where the authors of this review are based), two major water treatment companies recover and spread $\sim 86,000 \mathrm{t}$ of WTRs per year to land. It is easy to recognise the potential benefits of land applying WTRs; for example, they have a high organic matter content, often a degree of liming capacity, and are a potential source of nutrients. Moreover, recovery and use in this way promotes the waste hierarchy concept as per the EU Waste Framework Directive (2008/98/EC) and facilitates development of a circular economy. Indeed, land application of WTRs has reportedly resulted in yield increases in various plants and other soil benefits such as increased aeration and hydraulic conductivity (e.g. Geertsema et al. (1994), Ahmed et al. (1998)), although the limitation of plant available $\mathrm{P}$ has occasionally been observed (see Section 5.4.2).

There are many variables to consider in the application of WTRs to agricultural land including the cropping system, crop nutrient requirement, time of year and existing soil conditions. Methods of application tend to be split according to whether the WTRs are solid (approximately $14 \%$ dry matter or above) or liquid. Solid WTRs are generally spread using tractors using conventional manure spreaders, and trajectory splash plates or precision injection techniques such as a trailing shoe or dribble bar while spreading wet material. The rates of application are typically linked to plant or soil requirements, with maximum limits set according to local governing regulations. In the UK for example, the maximum application rate permitted is $250 \mathrm{t} \mathrm{ha}^{-1}$ with a further limit on liquid applications of $50 \mathrm{~m}^{3} \mathrm{ha}^{-1}$ at any one time, and additionally no more than $250 \mathrm{~kg} \mathrm{~N}^{-1}$ may be applied to land (DEFRA 2011; Environment Agency 2013).

\subsubsection{Land Application for General Soil Improvement}

The use of WTRs in potting mix and other plant growth media has also been explored; for example Bugbee and Frink (1985) included experimentation with Al WTRs as a component of potting mixtures at rates of $25 \%$, $50 \%, 75 \%$ and $100 \%$ combined with soil. The authors noted a general increase in aeration of the potting mix that was related to the WTR additions while the impacts on available water, pore space and bulk density variations were minimal or negligible. However, they did note reduced growth of marigolds (Tagetes sp.) and that lettuce (Lactuca sativa) had developed a purple hue when grown in a WTR-containing potting media which they associated with $\mathrm{P}$ deficiency at these high proportions of WTR (as per the discussion in Section 5.4.2).

Heil and Barbarick (1989) found that low $\left(5 \mathrm{~g} \mathrm{~kg}^{-1}\right)$ application rates of $\mathrm{Al}$ and Fe WTRs to soils increased yield of sorghum-sudangrass (Sorghum bicolor L. Moench), attributed to their $\mathrm{Fe}$ contributions and $\mathrm{pH}-$ increasing abilities. During trials of co-application of WTRs and vermicomposts, Ibrahim et al. (2015) found that a 2:1 ratio of WTR to vermicompost with a combined application rate of $5 \mathrm{~g} \mathrm{~kg}^{-1}$ resulted in greater wheat yields than all other treatments tested, which included pure vermicompost and control (i.e. dried and sieved soil only) treatments. WTRs were found to serve as a better planting medium for peppers (Capsicum 
annuum 'Takanotsume') than granite parent materialbased soils when both were amended with $10 \%$ additions of compost (Park et al. 2010). This was believed by the authors to be related to the higher gas diffusivity, saturated hydraulic conductivity, $\mathrm{N}$ content and cationexchange capacity following WTR addition. During a study into the effects of ageing soils treated with WTRs for 1.5 years ( $7.5 \mathrm{t} \mathrm{ha}^{-1}$ application rate), Mukherjee et al. (2014) found that many physical properties of the soils remained the same as those of control soils; however, there were minor but significant increases in electrical conductivity from 7.1 to $7.5 \mu \mathrm{S} \mathrm{m}^{-1}$ and a penetration resistance (i.e. soil strength) increase of $87 \%$. However, these impacted factors were unlikely to have any major implications for soil use. One study did report reductions in Chinese cabbage (Brassica pekinensis (Lour.) Rupr.) biomass when WTR application rates above $2 \%(\mathrm{w} / \mathrm{w})$ despite fertiliser addition, highlighting the possibility that high WTR addition rates can render the conditions of the treated soil sub-optimal for growth of some plants (Tay et al. 2017).

The use of WTRs as an amendment to soil substrates that are used for plant growth (i.e. as opposed to land upon which buildings are to be constructed) appears to be a positive reuse of WTRs that has multiple benefits for the environment. There is evidence of improved plant growth in a majority of cases when WTRs are applied alongside a P source (e.g. fertiliser or compost), which is often the way applications are made in realworld agricultural settings. The added potential benefit of reducing plant uptake of some PTEs could make this use of WTRs of particular benefit to agricultural production in areas that have contaminated soils requiring management and remediation, and this is addressed in Section 5.4.3. An additional benefit perceived by land owners is that the sulphur content of WTRs may also provide a nutrient benefit to plant production, but this has not been examined or reported in the literature to date and is thus an area warranting investigation.

\subsubsection{Grazing Animals and Poultry}

Grazing animals obtain a large proportion of their foodstuffs from the soil surface, and it is known that grazers such as sheep typically ingest considerable quantities of soil while grazing (e.g. 1-6 g soil/kg body mass/day, or up to $400 \mathrm{~g} \mathrm{~kg}^{-1}$ body mass across a growing season (McGrath et al. 1982)); this raises considerations about potential implications for grazers in relation to surface application of WTRs.

Van Alstyne et al. (2007) investigated the impacts of feed containing Al WTRs on lambs when compared with feed containing a sand control or a more available Al source $\left(\mathrm{AlCl}_{3}\right)$. The highest WTR treatment rate imposed (10\% of the feed by mass; $8000 \mathrm{mg} \mathrm{Al} \mathrm{kg}-1$ total feed) was considered a proxy for a very high WTR field application rate $\sim 225$ dry metric tonnes $\mathrm{ha}^{-1}$. It was concluded that any minor fluctuations in measured parameters (feed intake, body weight, $\mathrm{P}$ absorption or $\mathrm{P}$ availability in blood plasma) between some WTR treatments and the controls were not a risk to lamb health, although it was suggested that $P$ should also be supplied at $0.25 \mathrm{wt} \%$. Madison et al. (2009) investigated the effects of land application of WTRs on grazing cattle over a 2-year period. Over that time, $75.8 \mathrm{t} \mathrm{ha}^{-1}$ of WTRs were surface applied. It was found that cattle were unaffected (in terms of weight gain and tissue mineral concentrations) due to the low bioavailability of the components in the WTRs. Maurice et al. (1998) mixed $20 \%$ alum WTR and $10 \%$ zeolite into chicken feed and found that there were no significant impacts on health indicators (i.e. body weight, feed conversion or leg scores) of 3- to 6-week-old chickens. Additionally, litter characteristics including ammonia, $\mathrm{pH}, \mathrm{N}, \mathrm{P}$ and $\mathrm{Cu}$ were all also unaffected.

\subsubsection{Immobilisation of Contaminants and Excess Nutrients in Soil}

In addition to application onto unspoiled soils, WTRs have been investigated for their use in managing or restoring soils with excess nutrient or contamination problems. In this approach, the capability of WTRs to sorb contaminants and excess nutrients in soils is utilised to immobilise them in situ. Immobilisation of $\mathrm{P}$ and $\mathrm{N}$ in soil, with the aim of reducing nutrient run-off and subsequent accelerated eutrophication in receiving waters, is an area that has received much attention. For example, Gallimore et al. (1999) reported small plot trials in which Al WTRs were applied in two ways (broadcast, at rates equivalent to 11 and $45 \mathrm{t} \mathrm{ha}^{-1}$, and in buffer strips) to poultry manure amended soils. They found that run-off from simulated rainfall had $\mathrm{P}$ concentrations of $14 \mathrm{mg} \mathrm{L}^{-1}$ from control plots, $6 \mathrm{mg} \mathrm{L}^{-1}$ from $45 \mathrm{t} \mathrm{ha}^{-1}$ broadcast treatments and $7 \mathrm{mg} \mathrm{L}^{-1}$ from buffer strip plots while the $11 \mathrm{t} \mathrm{ha}^{-1}$ treatment caused no significant decrease when compared to control plots. 
Similarly, Codling et al. (2002) found that WTR application rates of $50 \mathrm{~g} \mathrm{~kg}^{-1}$ decreased water-soluble $\mathrm{P}$ and Mehlich 3-extractable phosphorus concentration by 98 99\% and $87-90 \%$ respectively. Likewise, Silveira et al. (2013) found that the treatments trialled (30 and $75 \mathrm{t} \mathrm{ha}^{-1}$ ) reduced water-extractable $\mathrm{P}$ in soil $\mathrm{A}$ and $\mathrm{E}$ horizons by more than $60 \%$ (e.g. $18.4 \mathrm{mg} \mathrm{kg}^{-1}$ in control soil A horizon, down to 7.3 and $2.8 \mathrm{mg} \mathrm{kg}^{-1}$ in 35 and $70 \mathrm{t} \mathrm{ha}^{-1}$ treatments respectively). The study by Silveira and co-workers also reported reductions in shallow ground water $\mathrm{P}$ (i.e. $60-\mathrm{cm}$ depth), reducing $\mathrm{P}$ from 1.0 to $0.43 \mathrm{mg} \mathrm{L}^{-1}$ and $0.20 \mathrm{mg} \mathrm{L}^{-1}$ in 35 and $70 \mathrm{t} \mathrm{ha}^{-1}$ treatments respectively, while in plots which were ploughed in order to incorporate WTRs produced reductions from $3.4 \mathrm{mg} \mathrm{L}^{-1}$ down to $1.4 \mathrm{mg} \mathrm{L}^{-1}$ and $0.5 \mathrm{mg} \mathrm{L}^{-1}$ respectively. This indicates that the act of ploughing, in this periodically anoxic soil, disturbed the soil matrix sufficiently to expose leachable $\mathrm{P}$ in control as well as treated plots. Comparable results have been produced in a laboratory setting also. For instance, work by Oladeji et al. (2008) demonstrated that surface application of Al WTRs at $10 \mathrm{~g} \mathrm{~kg}^{-1}$ reduced the leachate P concentration by $46-54 \%$ in sandy soils amended with either poultry manure or sewage biosolids. In soil column experiments, Al WTR surface applications of 124 and $248 \mathrm{tha}^{-1}$ have proven to assist in the reduction of leached P from urban runoff (Ippolito 2015). Similarly, field studies found that Al WTR application at 22.4 dry $\mathrm{t} \mathrm{ha}^{-1}$ can reduce leaching of $\mathrm{P}$ into shallow groundwaters (Agyin-Birikorang et al. 2009).

A number of studies have identified the potential for overefficient phosphorous sorption as a long-standing potential concern when it comes to land application of WTRs to agricultural soils, as it could restrict P supply to plants and subsequently risk sub-optimum nutrient levels or even P deficiency (Bugbee and Frink 1985; Elliott and Dempsey 1991). Lucas et al. (1994) linked this effect with yield reductions in tall fescue grass (Festuca arundinacea) when Al WTRs were applied above $1 \%$ or $2 \%$ by mass. More recently, Lombi et al. (2010) reported that a pot trial using two soils from South Australia amended with Al WTRs in which plant tissue $\mathrm{P}$ concentrations fell below critical levels at application rates approximating $10 \mathrm{tha}^{-1}$ and above. Other studies (e.g. Oladeji et al. (2007)) have also reported reduced plant tissue $\mathrm{P}$ concentrations in WTR-amended soil. However, the situation is not straightforward, as numerous studies have contrastingly shown no such $\mathrm{P}$ limitation or deficiency following WTR application, e.g.
Geertsema et al. (1994) and Ahmed et al. (1998), and certain reference sources cited in Elliott and Dempsey (1991). Long-term studies investigating this effect are rare, but a 3-year study reported by Geertsema et al. (1994) found that there were no significant differences in the P (or any other element) content of pine tree tissues grown in Al WTR-amended soils. Anecdotal evidence from the vast acreage of agricultural land across many countries that is now regularly amended with WTR applications, evidently without adverse effects that would deter land managers from continuing the practice, would support the notion that excessive $\mathrm{P}$ immobilisation in soil is not typically a problem. Nevertheless, the potential for excessive $\mathrm{P}$ restriction, particularly in already-P-deficient agricultural soils, remains a factor that must be considered in relation to planning land application of WTRs. One potential solution in such a situation was presented by Okuda et al. (2014), who demonstrated that by treating WTRs with sulphuric acid (principally to reduce the Al concentration via leaching), the plant availability of $\mathrm{P}$ within the WTRs increased. The authors found that Japanese mustard spinach (Brassica rapa var. perviridis, Komatsuna) $\mathrm{P}$ uptake was enhanced by $40 \%$ when grown in a treated WTR:peat mixture (50:50 ratio) when compared to a mixture containing untreated WTR sludge.

On the other hand, the use of WTRs as a fertiliser has also been explored. Rigby et al. (2013) explored the viability of using Al WTRs as a fertiliser in P- and $\mathrm{N}$-deficient sand. They found that WTRs supplied adequate quantities of plant available $\mathrm{N}$ and that their application resulted in grain yield increases for wheat (Triticum aestivum L. cv. Wilgoyne) relative to untreated control plots. However, produced yields were only $62 \%$ and $69 \%$ (years 1 and 2 respectively) of grain grown in plots which had received standard inorganic $\mathrm{P}$ and $\mathrm{N}$ fertiliser applications (Rigby et al. 2013). In order to address these issues, Zohar et al. (2017) produced a WTR-organic composite that could potentially find use as a slow-release $\mathrm{P}$ fertiliser; this was achieved by initially using WTRs to treat soil leachate and dairy wastewater to remove P. A 9-week desorption experiment found that $\mathrm{P}$ was slowly released, initially at a rate of $30 \mathrm{mg} \mathrm{kg}^{-1}$, which decreased to $10 \mathrm{mg} \mathrm{kg}^{-1}$ after 28 days and remained constant until the experiment concluded at 60 days. However, this preparation may not always be necessary as Silveira et al. (2013) highlighted that WTRs were an adequate substitute for organic-rich 
fertiliser in all but P-deficient soils when growing bahiagrass (Paspalum notatum Flüggé).

There have also been attempts to utilise WTRs to remediate or make safer soils known to be contaminated with PTEs such as, $\mathrm{Cd}$ and $\mathrm{Pb}$. Garau et al. (2014) trialled Fe WTRs and other waste materials in a study designed to assess immobilisation of PTEs (i.e. $\mathrm{Cd}, \mathrm{Cu}$, $\mathrm{Pb}, \mathrm{Zn})$ in a circum-neutral $\mathrm{pH}$ soil contaminated with As (2105 mg kg$\left.{ }^{-1}\right), \mathrm{Cd}\left(18 \mathrm{mg} \mathrm{kg}^{-1}\right), \mathrm{Cu}\left(264 \mathrm{mg} \mathrm{kg}^{-1}\right)$, $\mathrm{Pb}\left(710 \mathrm{mg} \mathrm{kg}^{-1}\right)$ and $\mathrm{Zn}\left(522 \mathrm{mg} \mathrm{kg}^{-1}\right)$. The amendments were added at $3 \%$ by mass and equilibrated for 6 months after which plant growth, element mobility, microbial diversity and microbial function were assessed. They found a $27 \%$ reduction in the non-specifically adsorbed (i.e. readily mobile) As in Fe WTR treatments, as well as reductions in $\mathrm{Ca}\left(\mathrm{NO}_{3}\right)_{2}$-extractable $\mathrm{Cd}, \mathrm{Pb}$ and $\mathrm{Zn}$. The authors observed a 2.5 -fold increase in plant yield for the common bean (Phaseolus vulgaris) and a 1.8-fold increase for wheat (Triticum vulgare) grown in WTR-treated soil and, importantly, the yield increases could be directly attributed to reduced toxicity through contaminant immobilisation rather than to any changes in $\mathrm{pH}$ or nutrient addition. However, while WTR treatment resulted in a significant decrease in shoot As concentration in wheat (from $\sim 39$ to $21 \mu^{-1}$ ), a conflicting result was noted for bean where the shoot As concentration increased (from $\sim 50$ to $60 \mu \mathrm{g}^{-1}$ ).

Nagar et al. (2015) investigated the long-term (3-year) effect of incorporating $\mathrm{Al}$ and Fe WTRs, separately, on As bioaccessibility in two As-spiked soils with contrasting properties (a sandy soil with $\mathrm{pH} 4.05$ and a sandy clay loam with $\mathrm{pH}$ 7.85). The authors found that bioaccessible As, determined via the in vitro gastrointestinal simulation, was reduced by 50 to $80 \%$ when compared with non-WTR-treated soils for both Al and Fe WTRs at both rates of application tested $(5 \%$ and $10 \% \mathrm{w} / \mathrm{w})$. It was also reported by the same research group that As sorption decreased as $\mathrm{pH}$ increases under As loads of 1875 and $3750 \mathrm{mg} \mathrm{kg}^{-1}$ applied to a sandy soil, while this effect was undetectable under a lower As load of $125 \mathrm{mg} \mathrm{kg}^{-1}$ (Nagar et al. 2013). Contrary to the findings of Gibbons and Gagnon (2011) and Castaldi et al. (2014), who both observed Fe WTRs to have greater As and P sorbing capacity than Al WTRs, a study by Nagar et al. (2013) reported Al WTRs to have achieved a greater As sorption than Fe WTRs in the soils they tested (see Table 5).

Other studies focusing on contaminant metals in soil have also found reductions in mobility or availability following WTR application. For example, Elkhatib and
Moharem (2015) explored the effect of WTR application on the non-residual fraction (i.e. the fraction considered potentially mobile or bioavailable), determined by the Tessier et al. (1979) sequential extraction method, of $\mathrm{Cu}, \mathrm{Pb}$ and $\mathrm{Ni}$ in calcareous and sandy agricultural soils; the results of this study can be seen in Fig. 5.

As with water studies, there have also been attempts to incorporate nWTRs into soils. When mixed with Cdand $\mathrm{Pb}$-spiked soils (spiked at 50, 100 and $150 \%$ of the soil metal concentration limits suggested by USEPA), incorporation of $0.3 \%$ by mass nWTRS led to a $>99 \%$ reduction in phytoavailability (Brassica napus L.) of both $\mathrm{Pb}$ and $\mathrm{Cd}$ (Elkhatib et al. 2018).

There have been several attempts to co-apply WTRs alongside other organic wastes such as sewage biosolids (Maurice et al. 1998; Ippolito et al. 2009a; Mahdy et al. 2009). Co-application of WTRs and biosolids was shown to increase corn yield proportionally to WTR concentration up to an application rate of $3 \%$ by weight, above this point yield decreased (Mahdy et al. 2009). This was matched by a corresponding effect on P uptake, while no phytotoxicity was observed (Mahdy et al. 2009). The long-term (13-15 years) impacts of a single application and short-term (2-4 years) impacts of repeated co-applications of WTRs and biosolid amendments to semi-arid grasslands were investigated by Ippolito et al. (2009a). They found that ammonium bicarbonate-diethylenetriaminepentaacetic acidextractable $\mathrm{Cd}, \mathrm{Cu}, \mathrm{Fe}, \mathrm{Mn}, \mathrm{Ni}$ and $\mathrm{Zn}$ and soil $\mathrm{pH}$, $\mathrm{EC}, \mathrm{NO}_{3}-\mathrm{N}, \mathrm{NH}_{4}-\mathrm{N}$, total $\mathrm{C}$ and total $\mathrm{N}$ showed no significant change under a single WTR-biosolid application; however. a majority of these increased under repeated applications (Ippolito et al. 2009a). Unfortunately, this study did not compare results to those of a plot containing only biosolid amendments and thus it is difficult to distinguish the influence of each amendment. Tay et al. (2017) outlined a project that aimed to maximise the benefits of WTR amendments while minimising $\mathrm{P}$ immobilisation by co-applying $\mathrm{P}$ fertilisers, as had been recommended previously (Elliott and Dempsey 1991; Lucas et al. 1994). This combined application produced no significant difference in total plant tissue $\mathrm{P}$ concentration relative to controls but did reduce plant tissue As and Cd concentrations when WTR amendments to the sandy loam soil tested remained between 2 and $4 \%$.

Land application of WTRs, or use as a component in plant growing media, is therefore well justified as an increasingly common recovery and reuse option. As 
Fig. 5 The bioavailable fraction of $\mathrm{Cu}, \mathrm{Pb}$ and $\mathrm{Zn}$, as determined by the Tessier et al. (1979) sequential extraction method, before and after WTR application to soils. Data extracted from Elkhatib and Moharem (2015)

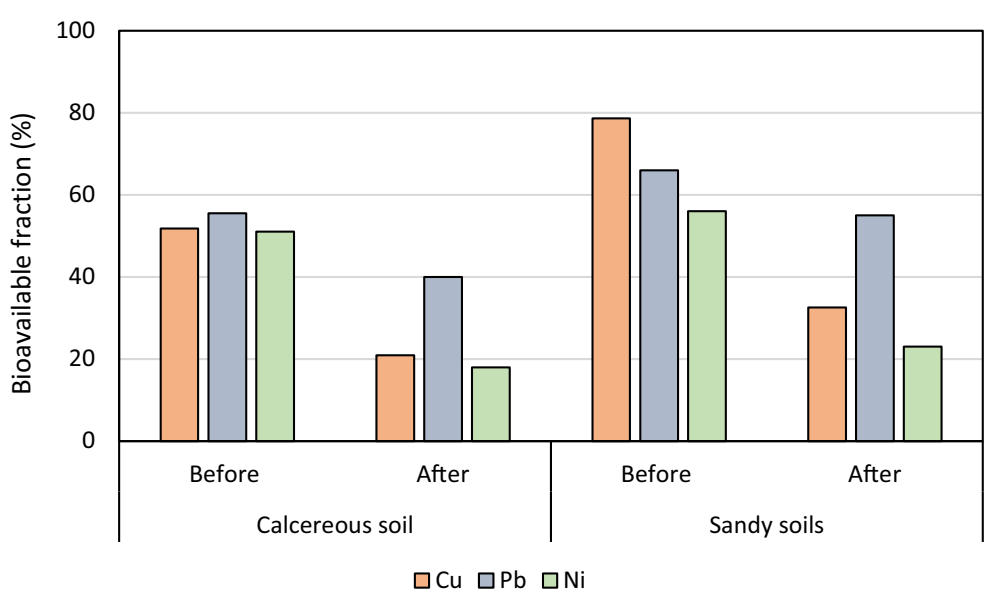

well as for use on productive agricultural land, the literature indicates that WTR application on degraded or contaminated soils can help realise benefits through reducing plant uptake and mobility of PTEs and other contaminants. However, there are remaining questions that need to be answered in terms of the full range of influences and benefits that WTRs can have on soil chemistry and ecology once applied. This is explored further in Section 6.

\subsection{Use in Construction Materials}

Research into the use of WTRs in construction materials has been limited when compared with other potential beneficial uses and this is likely due to concerns that arise from the variability of physical properties of products produced from WTRs (Babatunde and Zhao 2007). This is brought about by their variability in chemical composition, water content and organic matter content. However, a general geotechnical evaluation of alum sludge found that, when mixed with zeolite Al sludge produces a material which is suitable for use in a variety of geotechnical and geoenvironmental applications due to its high shear strength, mechanical stability and low permeability (Balkaya 2015). This along with other studies suggests that WTRs can be used in construction, as long as the correct pre-treatment (i.e. dewatering and drying at $105^{\circ} \mathrm{C}$ ) is applied and they are mixed with the correct materials.

\subsubsection{Clay Bricks}

Due to the similarities in the chemical composition of brick clay and WTRs, production of bricks with a partial replacement of clay with WTRs could offer a large reuse pathway for WTRs. Multiple experiments have explored incorporating WTRs into bricks (Table 7). Initial studies explored the combined additions of WTRs and sewage sludge ash (Anderson et al. 2003; Golbold et al. 2003). Anderson et al. (2003) documented the use of WTR and sewage sludge incineration ash as a combined $5 \%$ by weight addition to brick production. Preliminary results of that study facilitated the rollout of a full-scale factory trial producing 100,000 bricks. Multiple other studies have suggested that 15-20\% WTR additions are optimum to comply with a variety of national regulations, including those in India, Taiwan, Britain and Malaysia (Huang et al. 2005; Elangovan and Subramanian 2011; Shamsudin et al. 2017). Leaching testing has also confirmed that bricks produced with up to $2.5 \%$ WTR content complied with the relevant national (British) Standards (Anderson et al. 2003). Bricks containing much higher WTR sludge content, 50-80\% sludge, and those containing solely WTRs, rice husk ash and silica fume, were found to generally be of superior quality to those available locally in some areas of Egypt (Ramadan et al. 2008; Hegazy et al. 2012). Therefore, in areas where brick production standards are less stringent or the availability of quality bricks is limited, the use of WTRs in brick production could be of particular benefit. However, in order to produce bricks containing higher amounts of WTRs, the sintering temperature of the bricks must be increased to $\sim 1050-1100{ }^{\circ} \mathrm{C}$ due to the lower silica content and higher water content of WTRs, thus making the brick production process more energy intensive at these rates and therefore making the process less economically and environmentally appealing. Furthermore, Anderson et al. (2003) noted that 
Table 7 The outcomes of studies into the incorporation of WTRs into the brick manufacturing process

\begin{tabular}{|c|c|c|c|c|c|}
\hline $\begin{array}{l}\text { Country of } \\
\text { study }\end{array}$ & $\begin{array}{l}\text { Sludge } \\
\text { content }\end{array}$ & Other component materials & $\begin{array}{l}\text { Sintering } \\
\text { temperature } \\
\left({ }^{\circ} \mathrm{C}\right)\end{array}$ & Outcome & Reference \\
\hline $\begin{array}{l}\text { United } \\
\text { Kingdom }\end{array}$ & $0-2.5 \%$ & $\begin{array}{l}2.5 \% \text { sewage sludge incineration ash and } \\
95 \% \text { clay }\end{array}$ & 1050 & $\begin{array}{l}\text { Additions had no significant impact on } \\
\text { compressive strength, water } \\
\text { absorption or efflorescence. }\end{array}$ & $\begin{array}{l}\text { (Anderson } \\
\text { et al. 2003) }\end{array}$ \\
\hline India & $0-50 \%$ & Clay & $700-950$ & $\begin{array}{l}20 \% \text { WTR was optimum, although } \\
\text { compressive strength drops by } \\
15-50 \% \text { beyond } 15 \% \text { additions. }\end{array}$ & $\begin{array}{l}\text { (Elangovan } \\
\text { and } \\
\text { Subraman- } \\
\text { ian 2011) }\end{array}$ \\
\hline Malaysia & $0-30 \%$ & $\begin{array}{l}\text { The brick mixture was } 1: 2: 4 \text { of cement: } \\
\text { sand: soil + WTP residual solution. }\end{array}$ & $\begin{array}{l}\text { Not } \\
\text { specified }\end{array}$ & $\begin{array}{l}20 \% \text { WTR content was optimum for } \\
\text { bricks in order to comply with British } \\
\text { and Malaysian standards (BS 3921: } \\
1985 \text { and MS 7.6: } 1972 \text { respectively). }\end{array}$ & $\begin{array}{l}\text { (Shamsudin } \\
\text { et al. 2017) }\end{array}$ \\
\hline Taiwan & $0-30 \%$ & $\begin{array}{l}\text { The remainder of the brick mixture was } \\
\text { made up of excavation waste soil. }\end{array}$ & $850-1050$ & $\begin{array}{l}\text { Up to } 15 \% \text { WTRs could be included in } \\
\text { bricks that still meet the Taiwanese } \\
\text { National Science Council's } \\
\text { specification for a first-grade brick, } \\
\text { while additions between } 15 \text { and } 30 \% \\
\text { can be used to produce second- or } \\
\text { third-class bricks. However, the } \\
\text { sintering temperature of the bricks } \\
\text { must be increased from } 950 \text { to } \\
1050{ }^{\circ} \mathrm{C} \text {. }\end{array}$ & $\begin{array}{l}\text { (Huang et al. } \\
\text { 2005) }\end{array}$ \\
\hline Egypt & $50-80 \%$ & Clay & $950-1100$ & $\begin{array}{l}50 \% \text { WTR content was optimum } \\
\text { although no control was tested. }\end{array}$ & $\begin{array}{l}\text { (Ramadan } \\
\text { et al. 2008) }\end{array}$ \\
\hline Egypt & $0-50 \%$ & $\begin{array}{l}\text { The remainder of the brick mixtures } \\
\text { contained } 50-75 \% \text { combinations of } \\
\text { silica fume and rice husk ash, while } \\
\text { the control consisted of } 100 \% \text { clay. }\end{array}$ & $950-1100$ & $\begin{array}{l}\text { WTR content increased compressive } \\
\text { strength at higher sintering } \\
\text { temperatures }(>1100 \mathrm{C}) \text { compared to } \\
100 \% \text { clay bricks. }\end{array}$ & $\begin{array}{l}\text { (Hegazy et al. } \\
\text { 2012) }\end{array}$ \\
\hline Portugal & $0-5 \%$ & Clay & $\begin{array}{l}\text { Not } \\
\text { specified }\end{array}$ & $\begin{array}{l}\text { WTR additions improved thermal } \\
\text { transmittance and therefore better for } \\
\text { insulation purposes. }\end{array}$ & $\begin{array}{l}\text { (Santos et al. } \\
\text { 2015) }\end{array}$ \\
\hline
\end{tabular}

additional investment in equipment was required by the brick-making industry in order to achieve the required blending of materials.

\subsubsection{Cement, Concrete and Aggregates}

There have also been attempts to incorporate WTRs into cements (Huang et al. 2005; Chen et al. 2010; Yen et al. 2011) and concretes (Kaosol 2010; Sales et al. 2011; Lee et al. 2012; Owaid et al. 2017) (Table 8). The production processes related to these materials do not include a sintering step; consequently, Rodríguez et al. (2010) found that additions as small as $10 \%$ were enough to retard the hydration rates of mortars which in turn increased the duration of the production process by over $12 \mathrm{~h}$. Multiple studies reported that increasing WTR additions reduced mechanical or compressive strength
(Rodríguez et al. 2010; Owaid et al. 2017), although Chen et al. (2010) noted that these changes only occurred above $7 \%$ additions while increases in strength were produced below $7 \%$ additions. In order to address this issue, Lee et al. (2012) produced a concrete with $30 \%$ sludge with additions and $2 \%$ of a solidification agent (main components $\mathrm{CaSO}_{4}(61.5 \%)$ and $\mathrm{CaO}$ $(31.4 \%))$ and achieved an acceptable mechanical strength according to the ASTM International standards (ASTM C117-04). As with bricks produced from WTRs, the leachates of these bricks had a low content of many common PTEs, specifically $\mathrm{Cd}, \mathrm{Cr}, \mathrm{Cu}, \mathrm{Ni}, \mathrm{Pb}$ and $\mathrm{Zn}$ (Huang et al. 2005; Chen et al. 2010). It has been suggested that the high proportion of silica $\left(\mathrm{SiO}_{2}\right)$ in some WTRs allows for the formation of calcium silicate $\left(\mathrm{Ca}_{2} \mathrm{SiO}_{4}\right)$ when combined with lime; this process provides the majority of set cements strength. The 
Table 8 A summary of past studies in producing cement, concrete and aggregates produced from WTRs

\begin{tabular}{|c|c|c|c|c|c|}
\hline $\begin{array}{l}\text { Country } \\
\text { of study }\end{array}$ & $\begin{array}{l}\text { Material } \\
\text { produced }\end{array}$ & $\begin{array}{l}\text { Sludge } \\
\text { content }\end{array}$ & Other component materials & Outcome & Reference \\
\hline China & $\begin{array}{l}\text { Artificial } \\
\text { aggregate } \\
\text { and } \\
\text { cement }\end{array}$ & $\begin{array}{l}\text { Not } \\
\text { specified }\end{array}$ & Excavation waste soil & $\begin{array}{l}\text { Aggregates required sintering at high } \\
\text { temperatures to achieve } \\
\text { construction standards. }\end{array}$ & (Huang et al. 2005) \\
\hline Malaysia & Concrete & $0-25 \%$ & $\begin{array}{l}\text { Silica fume, ground granulated blast } \\
\text { furnace slag, palm oil, fuel ash and } \\
\text { cement in varying ratios }\end{array}$ & $\begin{array}{l}\text { Decline in compressive strength of } \\
\text { concrete containing thermally } \\
\text { activated alum sludge ash (AASA) } \\
\text { was found to correlate with the } \\
\text { concentrations of AASA. }\end{array}$ & (Owaid et al. 2017) \\
\hline Thailand & $\begin{array}{r}\text { Concrete } \\
\text { blocks }\end{array}$ & $0-50 \%$ & $\begin{array}{l}\text { A mixture of powdered Portland } \\
\text { cement, sand and crushed stone } \\
\text { dust }\end{array}$ & $\begin{array}{l}\text { 10-20\% WTRs could be used in } \\
\text { hollow load bearing concrete } \\
\text { blocks, while up to } 50 \% \text { can be } \\
\text { used in hollow non-load bearing } \\
\text { concrete block. }\end{array}$ & (Kaosol 2010) \\
\hline Brazil & Concrete & $52 \%$ & $\begin{array}{l}\text { A composite was made of sawdust, } \\
\text { sludge and water }(1: 6: 4.5) \text { and } \\
\text { added to concrete made of } \\
\text { cement:sand:composite:water } \\
\text { mass ratios of } 1: 2.5: 0.67: 0.6 \text {. }\end{array}$ & $\begin{array}{l}\text { Suitable for application in } \\
\text { non-structural elements }\end{array}$ & (Sales et al. 2011) \\
\hline Taiwan & Cement & $10 \%$ & $\begin{array}{l}39.4 \% \text { marble sludge, } 10 \% \text { water } \\
\text { treatment sludge, } 1.8 \% \text { basic } \\
\text { oxygen furnace, } 39.4 \% \text { limestone } \\
\text { and } 9.5 \% \text { sand }\end{array}$ & $\begin{array}{l}\text { Sludge containing WTRs had higher } \\
\text { compressive strength than } \\
\text { conventionally produced cement } \\
\text { after } 28 \text { days of ageing. }\end{array}$ & (Yen et al. 2011) \\
\hline China & Cement & $0-10 \%$ & $\begin{array}{l}\text { Shale at } 0-15 \%, 80.9-81.5 \% \\
\text { limestone, } 0-5.8 \% \text { sand, } 2.5-2.9 \% \\
\text { copper waste and } 0.4-0.5 \% \\
\text { aluminium hydroxide }\end{array}$ & $\begin{array}{l}\text { Cement containing up to } 5.5 \% \text { sludge } \\
\text { had a higher compressive strength } \\
\text { than conventionally produced } \\
\text { cement; however, additions of } \\
\geq 7 \% \text { led to a significant decrease } \\
\text { in compressive strength after } \\
\text { ageing for } 28 \text { days. }\end{array}$ & (Chen et al. 2010) \\
\hline Taiwan & Concrete & $0-30 \%$ & $\begin{array}{l}0-6 \% \text { of a solidification agent (main } \\
\text { components } \mathrm{CaSO} 4(61.5 \%) \text { and } \\
\mathrm{CaO}(31.4 \%))\end{array}$ & $\begin{array}{l}\text { Achieved an acceptable mechanical } \\
\text { strength according to the ASTM } \\
\text { International standards (ASTM } \\
\text { C117-04) at the maximum WTR } \\
\text { content with as low as } 2 \% \text { solidi- } \\
\text { fication agent. }\end{array}$ & (Lee et al. 2012) \\
\hline
\end{tabular}

production of WTR-based products has a clear economic driver, as hollow concrete blocks produced containing $10-50 \%$ WTRs were found to reduce the cost of production by $12-41 \%$ respectively (Kaosol 2010).

\subsubsection{Ceramics}

In the production of ceramics, the addition of alum sludge up to $30 \%$ by weight alongside co-application of a silicate-based fluxing agent has been found to produce physically similar ceramics to the regular production process; additionally, these new WTR ceramics were resistant to leaching (Vicenzi et al. 2005). However, another study by Teixeira et al. (2011) found that additions of $10-20 \%$ of $\mathrm{Fe}$ WTRs led to a reduction in flexural strength and specific mass, while also increasing water absorption, highlighting the need for a fluxing agent. Kizinievič and Kizinievič (2017) and Kizinievič et al. (2013) found that increasing the Fe WTR content of ceramics had the following impacts on its properties: lower density and compressive strength, while increasing shrinkage, water adsorption and porosity. Additionally, it has been commented that Fe WTRs have an impact on the colouration of ceramics; therefore, they may be used as a substitute for dark red pigment. Wang et al. (1998) also found that leachates from WTR-containing ceramics complied with the Taiwan EPA guidelines. 


\subsubsection{Landfill Coating and Daily Cover}

A more novel construction use is that of a hydraulic barrier and as a daily cover material for landfill which is applied to minimise interaction between wastes and the air while also producing a solid base for vehicles to manoeuvre. WTRs can be used effectively for these purposes and provide similar results to other commonly used materials such as soil, paper sludge or tyre-derived aggregates (Balkaya 2016). In keeping with this idea, Caniani et al. (2013) produced a bio-soil from the stabilized organic fraction of municipal solid waste, $\mathrm{Al}$ sludge and clinoptilotite (a type of zeolite) which proved to be a successful barrier layer for landfill in terms of chemical and physical properties and leaching tests.

\subsubsection{Construction Summary}

To summarise, the use of WTRs in construction is a potentially useful and beneficial end use, with perhaps the greatest scope for this being found in regions or countries where high-quality building materials are less available, as suggested by some brick-based studies (Ramadan et al. 2008; Elangovan and Subramanian 2011). The additional requirements such as higher sintering temperature (Huang et al. 2005), longer production times (Rodríguez et al. 2010) and fluxing/ solidifying agents (Vicenzi et al. 2005; Lee et al. 2012) when WTRs are used in high percentage rates in bricks means that additional development is required in this area. Nevertheless, positive results have been obtained from research into the use of WTRs in brick and ceramic production that could have widespread ramifications for the reuse of WTRs.

\subsection{Coagulant Recovery and Reuse}

Coagulant recovery (CR) offers a viable alternative endof-life use for WTRs, which has the additional benefit of reducing the amount of WTRs produced as well as reducing disposal costs (Keeley et al. 2014). During $\mathrm{CR}$, acid is applied to water treatment sludge to redissolve spent coagulant metals (predominantly $\mathrm{Al}$ or $\mathrm{Fe}$ ). Following this step, undesirable contaminants are separated through varying separation processes. CR was popular during the 1970s and 1980s due to more lenient legislation for water quality (Keeley et al. 2014). However, its use was eventually ended due to issues relating to the accumulation of acid soluble impurities and the overall variability of WTRs.

Current methods can reliably recover $>70 \%$ coagulant metals, effectively reducing sludge volumes by $60 \%$ (Keeley et al. 2014). Abdo et al. (1993) reported that recovered coagulants were only $80 \%$ as efficient as fresh coagulants during water treatment. Xu et al. (2009) also measured the efficiency of recovered alum and found that turbidity, $\mathrm{UV}_{254}$ and $\mathrm{COD}$ removal efficiencies were $96 \%, 46 \%$ and $53 \%$ respectively of those that fresh alum displays. One of the greatest difficulties facing $\mathrm{CR}$ is ensuring that the benefits of the process outweigh the chemical (mainly acids) and energy costs.

Alternatively, direct reuse of WTRs in the treatment of wastewater has shown promise (Xu et al. 2016b). WTRs can be used as a substitute for $40 \%$ of the required fresh coagulant while producing no significant difference in all measured parameters of outlet water when applied to low turbidity water (Xu et al. 2016b). Suman et al. (2017) found that WTRs produced better removal results than conventional coagulants when treating dairy wastewater. The two-pronged reduction in WTRs obtained through this process make it an ideal reuse option; however, further study is required.

Further data on the full-scale possibilities of CR and coagulant reuse is required. Although CR may not currently be viable, it has potential in the future as recovery technologies advance and the process can be streamlined. Until that time, recovered coagulant and alum sludge can both be used in wastewater treatment in regions where regulations are less strict (Keeley et al. 2014; Xu et al. 2016b).

\section{Environmental and Ecological Impacts and Concerns}

Despite land application of WTRs now being a wellestablished and increasingly common practice, the most frequently raised concerns in published literature related to the use of WTRs in the open environment are the possibilities for the leaching of metals (especially $\mathrm{Al}$ ) and the immobilisation of too much P.

Aluminium is a nonessential metal which, in humans, has been related to a number of neurological and respiratory diseases, renal failure and 
bone damage when present above critical threshold concentrations (Krewski et al. 2007). The negative effects of $\mathrm{Al}$ on fish and invertebrates are also well established (Herrmann and Frick 1995). However, concerns about $\mathrm{Al}$ regarding the use of WTRs in land application do not centre around any risks to human health, but relate rather to the risk of $\mathrm{Al}$ toxicity to plants and soil biota. Aluminium is abundant in the environment, accounting for $\sim 7-11 \%$ (by mass) of the Earth's upper crust (Hu and Gao 2008) and forming one of the main constituents of many soils. However, Al toxicity generally becomes a concern when a soil $\mathrm{pH}$ is below 5 because of greater quantities of soluble aluminium (i.e. $\mathrm{Al}^{3+}$ and $\mathrm{AlOH}^{2+}$ ) being released into the porewater (Brady and Weil 2008). Howells et al. (2018) highlighted the importance of placing some restrictions on the conditions in which WTRs are used, finding that the leachable fraction of $\mathrm{Al}$ (i.e. $0.001 \mathrm{M} \mathrm{CaCl}_{2}$-extractable $\mathrm{Al}$ ) from Al WTRs increased from $4.5 \mathrm{mg} \mathrm{kg}^{-1}$ at a $\mathrm{pH}$ of 5.5 to $382 \mathrm{mg} \mathrm{kg}^{-1}$ at a $\mathrm{pH}$ of 4.4 . This is reflected in legislation and environmental regulation of some regions, an example of which is in England and Wales where the application of $\mathrm{Al}$ WTRs is limited to soils above a $\mathrm{pH}$ of 6 due to the increased mobility of $\mathrm{Al}$ below a $\mathrm{pH}$ of 5 in soils, while Fe WTRs are limited to application to soils above a pH of 5 (Environment Agency 2013). A number of studies have examined the leachability of Al from WTRs and the bioavailability of the Al contained within them, while other studies have investigated the influence WTR application to land has on soil porewater Al concentrations and plant assimilation of $\mathrm{Al}$ (Bugbee and Frink 1985; Chiang et al. 2012; Caniani et al. 2013; Howells et al. 2018). Upon ageing WTRs through incubation, AgyinBirikorang and O'Connor (2009) found that WTRs required $\geq 6$ months of ageing to stabilise the most reactive $\mathrm{Al}$ forms (determined as $5 \mathrm{mM}$ oxalateextractable), therefore suggesting that fresh WTRs should be aged before being applied to land to alleviate such concerns. However, this has not been examined in detail or supported by other findings and thus warrants further investigation.

As discussed in Section 5.4.3, the sorption of $\mathrm{P}$ is a potential limiting factor when it comes to land application of WTRs, unless the WTRs are being deliberately applied to restrict mobility of excess $\mathrm{P}$ that arises from previous overuse of fertilisers and manures, etc. However, as alluded to previously, co-application of WTRs with mineral fertilizers or other nutrient input (i.e. manures, composts or biosolids) can circumvent this concern. Indeed, support for this approach can also be found in the review of legislation at a European level on WTR disposal by Hidalgo et al. (2016), which indicated that the most feasible use of WTRs from a regulatory standpoint is as an agricultural substrate when mixed with a nutrient source.

Despite these and other past studies that have shown little to no negative impact from WTR land application, WTRs are still considered hazardous wastes in some jurisdictions. For example, the Environmental Protection Agency (USA) ranks WTRs as having the second highest environmental impact potential (based on risk) of all effluent sources, contributing $10.7 \%$ of the national hazardous effluent production, although this figure is inflated by the hazard potential of chlorine residuals from other stages of the drinking water treatment process (EPA 2016). Having this kind of status may be pragmatic in one sense, i.e. in facilitating restriction of access and applications of WTRs to approved processes and practices, but in other ways it is a barrier to use as it imparts negative associations with the material and creates administrative and regulatory obstacles that must be overcome to enable use of the material. Research that better clarifies and quantifies any risks involved in the land application (or other uses) of WTRs would help to address this.

In terms of impacts on biota and ecosystems, while multiple studies have explored the direct effects of WTRs on aquatic ecosystems (Hall and Hall 1989; George et al. 1991; George et al. 1995; Kaggwa et al. 2001), there is limited coverage in the literature regarding the effects of WTRs on terrestrial ecology. This is a notable gap, especially considering that land application is an increasingly important disposal route. The information that is available in the literature on this aspect is discussed below.

\subsection{Microorganisms and Invertebrates}

Ippolito et al. (2009a) found that surface co-application of WTRs with biosolids at a rate of 5-21 tha ${ }^{-1}$ caused a minor enrichment on a subset of microbial community fatty acids, including markers for Gram-positive and Gram-negative bacteria after a period of 15 years, 
although it was suggested this increase was more closely related to biosolid addition than that of WTRs. However, the overall effect on plants and soil biology was minimal and was considered to pose no overall threat to the environment. Garau et al. (2014) found that Fe WTR amendments (3\% w/w addition rate) led to increased culturable heterotrophic bacteria and actinomycetes while having the opposite effect on heterotrophic fungi. Overall, they found the soil microbial biomass remained constant.

WTRs themselves are a source of some microorganisms; for example Oliver et al. (2011) verified that the abundance of microbes capable of proliferation under anaerobic conditions was comparable with that observed for soils, while Xu et al. (2018) determined that Proteobacteria, Cyanobacteria, Bacteroidetes, Firmicutes, Verrucomicrobia and Planctomycetes were the dominant phyla among the six Chinese WTRs they examined. Xu and co-workers also identified the presence of three genera of potentially toxic cyanobacteria (Planktothrix, Microcystis and Cylindrospermopsis), and four potential pathogens (Escherichia coli, Bacteroides ovatus, Prevotella copri and Rickettsia), with their abundances heavily influenced by the nutrient and $\mathrm{Fe}$ contents of the raw waters whose treatment generated the WTRs. This was in agreement with an earlier German study (Würzer et al. 1995) that determined WTRs could contain pathogenic bacteria, viruses and Protista.

However, Pecku et al. (2006) investigated the influence of $300 \mathrm{t} \mathrm{ha}^{-1}$ applications of WTRs on microbial indicators of soil quality (soil respiration, denaturing gradient gel electrophoresis and DNA analysis) and found no detrimental effects on any of the measured values. Nevertheless, although no negative impacts have been observed, the long-term influence of WTR addition on microbial population dynamics remains unknown. Howells et al. (2018) conducted survival, reproduction and avoidance tests with earthworms exposed to 0-20\% WTR-containing soils. Their study found that earthworm biomass, survival and reproduction were unaffected, although avoidance of soils containing $\geq$ $10 \%$ of Fe WTR and $20 \%$ Al WTRs was noted.

\section{Summary, Conclusions and Recommendations}

Despite a well-established continued level of WTR use in land applications, there are remaining questions regarding their utilisation in this sector. A key issue is the amount of published literature from utility companies and commercial trials in the public domain. Other end use markets exist but are less well researched and documented. With mounting environmental and economic pressure from the public and regulatory bodies, and the move away from landfill disposal, the need for sustainable and efficient outlets for WTRs continues. However, while research and publicly available data for other organic materials, such as sewage sludge, is widespread, information relating to by-products from the drinking water treatment process are not nearly as extensive. The gap in published data relating to WTRs and impacts associated with application to land in the UK highlights a need for an up-to-date review of information held by utility companies. The benefits, disadvantages and limitations of the various WTR use options examined in this paper are summarised in Table 9.

In summary, while it is known that WTRs can be utilised in multiple ways, there are still unexplored issues and potentially limiting factors. For example, while the use of WTRs in CWs is a disposal route that is viable, the lack of development of anti-clogging techniques is a prominent issue in the literature. Unfortunately, WTR-based CWs are unlikely to provide a large demand for WTRs due to the system long lifecycles. The adsorption qualities of WTRs are well documented, and while they are reportedly dependent on certain conditions such as $\mathrm{pH}$ (Hovsepyan and Bonzongo 2009; Zhou and Haynes 2011; Silvetti et al. 2015), the use of WTRs as a sorbent is still applicable in a majority of natural soils sufficing that their application is carefully assessed. Leaching of pollutants has been shown to be an unlikely problem in most environmental settings; however, there appears to remain somewhat of a disconnect between research findings, governing environmental policy and business enterprise regarding WTRs. Such disconnects can only be solved through the availability of more scientific evidence and through the communication of that evidence to policy makers. Nevertheless, land application has been identified as a commercially viable and, to the best available knowledge, an ecologically sound disposal route that can be further enhanced by the co-application of a $\mathrm{P}$ source when required. Alternatively, the $\mathrm{Al}$ removal methods suggested by Okuda et al. (2014) may offer another method of reducing $\mathrm{P}$ sorption by Al WTRs when required. The 
Table 9 A summary of the advantages and disadvantages of varying disposal routed for WTRs

\begin{tabular}{|c|c|c|c|c|}
\hline \multicolumn{3}{|c|}{ Potential market for end use } & \multirow{2}{*}{$\begin{array}{l}\text { Advantages } \\
\text { - Sorbs high amounts of individual or } \\
\text { multiple contaminants } \\
\text { - nWTRs have even greater sorption } \\
\text { capacities }\end{array}$} & \multirow{2}{*}{$\begin{array}{l}\text { Disadvantages } \\
\text { - Possible excessive P sorption } \\
\text { - Leaching of some elements and } \\
\text { compounds are still a concern }\end{array}$} \\
\hline Sorption & $\begin{array}{l}\text { Water } \\
\text { remediation }\end{array}$ & $\begin{array}{l}\text { Elemental } \\
\text { contaminants }\end{array}$ & & \\
\hline & & Textile dye & - Very high removal rates & $\begin{array}{l}\text { - Not economical currently } \\
\text { - Disposal of produced product } \\
\text { - Does not work for hydrophilic dyes }\end{array}$ \\
\hline & & $\begin{array}{l}\text { Organic } \\
\text { contaminants }\end{array}$ & $\begin{array}{l}\text { - Possibly remediation method for } \\
\text { emerging contaminants } \\
\text { - Could reduce chance of } \\
\text { eutrophication }\end{array}$ & - Lack of research \\
\hline & \multirow{2}{*}{\multicolumn{2}{|c|}{ Constructed wetlands }} & • High removal efficiencies & - Clogging \\
\hline & & & $\begin{array}{l}\text { - Proven success in incorporating } \\
\text { bio-sorption reactors and microbial } \\
\text { fuel cells }\end{array}$ & - Low demand for WTRs \\
\hline & \multicolumn{2}{|c|}{ Lakes and reservoirs } & $\begin{array}{l}\text { - Could reduce chance of } \\
\text { eutrophication through nutrient } \\
\text { control }\end{array}$ & $\begin{array}{l}\text { - Leaching of some elements still under } \\
\text { question }\end{array}$ \\
\hline & \multicolumn{2}{|l|}{ Soil remediation } & $\begin{array}{l}\text { - Can sorb high amounts of organic } \\
\text { and inorganic pollutants } \\
\text { - Reduction of P runoff could reduce } \\
\text { eutrophication }\end{array}$ & $\begin{array}{l}\text { - Potentially excessive P sorption } \\
\text { - May require co-application to negate } \\
\text { crop yield reduction in certain cir- } \\
\text { cumstances } \\
\text { - Potential impacts relating to leaching } \\
\text { of Al and Fe from coagulants }\end{array}$ \\
\hline \multicolumn{3}{|l|}{ Bulk land application } & $\begin{array}{l}\text { - Increases aeration } \\
\text { - Provides sufficient } \mathrm{N} \text { for plant } \\
\text { growth } \\
\text { - Can increase plant yield } \\
\text { - Increased hydraulic conductivity }\end{array}$ & $\begin{array}{l}\text { - Excessive } \mathrm{P} \text { sorption } \\
\text { - Co-application of } \mathrm{P} \text { source may be } \\
\text { required } \\
\text { - Worries regarding the leaching of } \\
\text { metals }\end{array}$ \\
\hline \multirow[t]{3}{*}{$\begin{array}{l}\text { Incorporation into } \\
\text { construction } \\
\text { materials }\end{array}$} & \multicolumn{2}{|l|}{ Bricks } & $\begin{array}{l}\text { - Could offer a disposal route for a } \\
\text { large quantity of WTRs } \\
\text { - Can reduce production costs } \\
\text { - Up to } 15-20 \% \text { WTR content will } \\
\text { pass a majority of standards }\end{array}$ & $\begin{array}{l}\text { - Higher sintering temperature may be } \\
\text { required } \\
\text { - Some leachates of concern } \\
\text { - Reduction in strength above } 15 \% \\
\text { WTR content }\end{array}$ \\
\hline & \multicolumn{2}{|c|}{ Concrete and cement } & $\begin{array}{l}\text { - Can reduce production costs } \\
\text { - Could offer a disposal route for a } \\
\text { large quantity of WTRs }\end{array}$ & $\begin{array}{l}\text { - Higher sintering temperature may be } \\
\text { required } \\
\text { - May require solidification agent } \\
\text { - Reduction in strength at higher WTR } \\
\text { content }\end{array}$ \\
\hline & \multicolumn{2}{|l|}{ Ceramics } & - May be used as a pigment & $\begin{array}{l}\text { - Can have an unwanted effect on } \\
\text { colouration } \\
\text { - Lower compressive strength } \\
\text { - Greater shrinkage of products }\end{array}$ \\
\hline \multirow[t]{2}{*}{$\begin{array}{l}\text { Coagulant recover } \\
\text { and reuse }\end{array}$} & \multicolumn{2}{|c|}{ Recovery of metals/coagulant } & $\begin{array}{l}\text { - Reduction of WTR production } \\
\text { - Has been economically viable in the } \\
\text { past } \\
\text { - Can recover }>70 \% \text { of coagulants }\end{array}$ & $\begin{array}{l}\text { - Expensive due to chemical costs and } \\
\text { processes involved } \\
\text { - Not economically viable currently } \\
\text { - Recovered coagulants are not as } \\
\text { efficient as fresh coagulants }\end{array}$ \\
\hline & \multicolumn{2}{|c|}{ Reuse in wastewater treatment } & $\begin{array}{l}\text { - Reduction of WTR production } \\
\text { - Efficient removal rates } \\
\text { - Reduces coagulant requirements for } \\
\text { the process }\end{array}$ & - Regulations may limit use \\
\hline
\end{tabular}


short- and long-term influence on the ecology and biogeochemical processes in soils treated with WTRs do however remain avenues that require further research. Construction is a mass disposal route for WTRs, which appears to be feasible (as seen in Anderson et al. (2003)); however, variations in the physical properties of WTRs make their incorporation into these materials difficult; therefore, further innovation is required to bring this disposal route into the commercial sector. Finally, recycling of the coagulant components of WTRs may not currently be economically feasible, but it offers a proven avenue for disposal if the costs related to the process become more favourable.

The nature of WTRs, with their highly variable physical and chemical structure, means that even after previous studies, further investigation of WTRs from a variety of water treatment plants and from different regions is required before any definitive conclusions can be drawn and applied widely. It may be the case that WTRs reuse would be best assessed on a case-by-case basis. Additional end use options should also be explored. Any issues related to WTRs are only further compounded by a lack of published figures relating to their production and disposal. A more comprehensive review of this data is required in order to give a more accurate picture of the required end use capacity for WTRs.

Acknowledgements This work is part of a research project funded by the UK National Productivity Investment Fund (NERC grant NE/R007314/1).

Open Access This article is distributed under the terms of the Creative Commons Attribution 4.0 International License (http:// creativecommons.org/licenses/by/4.0/), which permits unrestricted use, distribution, and reproduction in any medium, provided you give appropriate credit to the original author(s) and the source, provide a link to the Creative Commons license, and indicate if changes were made.

\section{References}

Abdo, M., Ewida, K., \& Youssef, Y. (1993). Recovery of alum from wasted sludge produced from water treatment plants. Journal of Environmental Science and Health, Part A: Environmental Science and Engineering \& Toxic and Hazardous Substance Control, 28, 1205-1216.

Agyin-Birikorang, S., \& O'Connor, G. (2007). Lability of drinking water treatment residuals (WTR) immobilized phosphorus. Journal of Environmental Quality, 36, 1076-1085.

Agyin-Birikorang, S., \& O'Connor, G. (2009). Aging effects on reactivity of an aluminum-based drinking-water treatment residual as a soil amendment. The Science of the Total Environment, 407, 826-834.

Agyin-Birikorang, S., Oladeji, O., O'Connor, G., Obreza, T., \& Capece, J. (2009). Efficacy of drinking-water treatment residual in controlling off-site phosphorus losses: a field study in Florida. Journal of Environmental Quality, 38, 10761085.

Ahmad, T., Ahmad, K., \& Alam, M. (2016). Sustainable management of water treatment sludge through 3 'R'concept. Journal of Cleaner Production, 124, 1-13.

Ahmad, T., Ahmad, K., \& Alam, M. (2017). Sludge quantification at water treatment plant and its management scenario. Environmental Monitoring and Assessment, 189, 453.

Ahmad, T., Ahmad, K., \& Alam, M. (2018). Characterization and constructive utilization of sludge produced in clariflocculation unit of water treatment plant. Materials Research Express, 5, 035511.

Ahmed, M., Grant, C. D., Oades, J. M., \& Tarrant, P. (1998). Use of water treatment sludge. Australian Water and Wastewater Association, 25, 11-16.

Anderson, M., Biggs, A., Winters, C. (2003). Use of two blended water industry by-product wastes as a composite substitute for traditional raw materials used in clay brick manufacture. Advances in Waste Management, Dundee. Thomas Telford Publishing, pp 417-426.

Asif, M. B., Majeed, N., Iftekhar, S., Habib, R., Fida, S., \& Tabraiz, S. (2016). Chemically enhanced primary treatment of textile effluent using alum sludge and chitosan. Desalination and Water Treatment, 57, 7280-7286.

Babatunde, A., \& Zhao, Y. (2007). Constructive approaches toward water treatment works sludge management: an international review of beneficial reuses. Critical Reviews in Environmental Science and Technology, 37, 129-164.

Babatunde, A., \& Zhao, Y. (2010). Leachability and leaching patterns from aluminium-based water treatment residual used as media in laboratory-scale engineered wetlands. Environmental Science and Pollution Research, 17, 13141322.

Babatunde, A., Zhao, Y., Burke, A., Morris, M., \& Hanrahan, J. (2009). Characterization of aluminium-based water treatment residual for potential phosphorus removal in engineered wetlands. Environmental Pollution, 157, 2830-2836.

Babatunde, A., Zhao, Y., \& Zhao, X. (2010). Alum sludge-based constructed wetland system for enhanced removal of $\mathrm{P}$ and OM from wastewater: concept, design and performance analysis. Bioresource Technology, 101, 6576-6579.

Bai, L., Wang, C., He, L., \& Pei, Y. (2014). Influence of the inherent properties of drinking water treatment residuals on their phosphorus adsorption capacities. Journal of Environmental Sciences, 26, 2397-2405.

Balkaya, M. (2015). Evaluation of the geotechnical properties of alum sludge, zeolite, and their mixtures for beneficial usage. Environmental Progress \& Sustainable Energy, 34, 10281037.

Balkaya, M. (2016). Evaluation of the use of alum sludge as hydraulic barrier layer and daily cover material in landfills: a finite element analysis study. Desalination and Water Treatment, 57, 2400-2412.

Basibuyuk, M., \& Kalat, D. (2004). The use of waterworks sludge for the treatment of vegetable oil refinery industry wastewater. Environmental Technology, 25, 373-380. 
Brady, N., \& Weil, R. (2008). Soil colloids: seat of soil chemical and physical acidity. Upper Saddle River: Pearson Education Inc..

Bugbee, G. J., Frink, C. R. (1985). Alum sludge as a soil amendment: effects on soil properties and plant growth. Connecticut Agricultural Station.

Butani, S., Mane, S. 2017. Coagulation/flocculation process for cationic and anionic dye removal using water treatment residuals. International Journal of Engineering Science (Oxford, U. K.) 13476.

Caniani, D., Masi, S., Mancini, I., \& Trulli, E. (2013). Innovative reuse of drinking water sludge in geo-environmental applications. Waste Management, 33, 1461-1468.

Caporale, A. G., Punamiya, P., Pigna, M., Violante, A., \& Sarkar, D. (2013). Effect of particle size of drinking-water treatment residuals on the sorption of arsenic in the presence of competing ions. Journal of Hazardous Materials, 260, 644-651.

Castaldi, P., Mele, E., Silvetti, M., Garau, G., \& Deiana, S. (2014). Water treatment residues as accumulators of oxoanions in soil. Sorption of arsenate and phosphate anions from an aqueous solution. Journal of Hazardous Materials, 264, 144-152.

CEC 1999. Council Directive 1999/31/EC of 26 April 1999 on the landfill of waste. Official Journal of the European Communities L. Legis, pp 1-19.

Chen, H., Ma, X., \& Dai, H. (2010). Reuse of water purification sludge as raw material in cement production. Cement and Concrete Composites, 32, 436-439.

Chiang, Y. W., Ghyselbrecht, K., Santos, R. M., Martens, J. A., Swennen, R., Cappuyns, V., \& Meesschaert, B. (2012). Adsorption of multi-heavy metals onto water treatment residuals: sorption capacities and applications. Chemical Engineering Journal, 200, 405-415.

Chu, W. (2001). Dye removal from textile dye wastewater using recycled alum sludge. Water Research, 35, 3147-3152.

Codling, E. E., Chaney, R. L., \& Mulchi, C. L. (2002). Biomass yield and phosphorus availability to wheat grown on high phosphorus soils amended with phosphate inactivating residues. I. Drinking water treatment residue. Communications in Soil Science and Plant Analysis, 33, 1039-1060.

Dassanayake, K. B., Jayasinghe, G. Y., Surapaneni, A., \& Hetherington, C. (2015). A review on alum sludge reuse with special reference to agricultural applications and future challenges. Waste Management, 38, 321-335.

Dayton, E., \& Basta, N. (2001). Characterization of drinking water treatment residuals for use as a soil substitute. Water Environment Research, 73, 52-57.

DEFRA. (2011). Protecting our water, soil and air. UK: The Stationery Office.

Deng, Y., Morris, C., Rakshit, S., Landa, E., Punamiya, P., \& Sarkar, D. (2016). Water treatment residuals and scrap tire rubber as green sorbents for removal of stormwater metals. Water Environment Research, 88, 500-509.

Doherty, L., Zhao, X., Zhao, Y., \& Wang, W. (2015). The effects of electrode spacing and flow direction on the performance of microbial fuel cell-constructed wetland. Ecological Engineering, 79, 8-14.

Elangovan, C., \& Subramanian, K. (2011). Reuse of alum sludge in clay brick manufacturing. Water Science and Technology: Water Supply, 11, 333-341.
Elkhatib, E. A., \& Moharem, M. L. (2015). Immobilization of copper, lead, and nickel in two arid soils amended with biosolids: effect of drinking water treatment residuals. Journal of Soils and Sediments, 15, 1937-1946.

Elkhatib, E., Mahdy, A., Sherif, F., \& Hamadeen, H. (2015a). Evaluation of a novel water treatment residual nanoparticles as a sorbent for arsenic removal. Journal of Nanomaterials, 2015,5 .

Elkhatib, E. A., Mahdy, A. M., Sherif, F. K., \& Salama, K. A. (2015b). Water treatment residual nanoparticles: a novel sorbent for enhanced phosphorus removal from aqueous medium. Current Nanoscience, 11, 655-668.

Elkhatib, E., Mahdy, A., Sherif, F., \& Elshemy, W. (2016). Competitive adsorption of cadmium (II) from aqueous solutions onto nanoparticles of water treatment residual. Journal of Nanomaterials, 2016.

Elkhatib, E. A., Sherif, F., Kandil, M., Mahdy, A., Moharem, M., Al-Basri, A. A. (2018). Using nanoparticles from water treatment residuals to reduce the mobility and phytoavailability of $\mathrm{Cd}$ and $\mathrm{Pb}$ in biosolid-amended soils. Environmental Geochemistry and Health, 1-12.

Elliott, H. A., \& Dempsey, B. A. (1991). Agronomic effects of land application of water treatment sludges. Journal American Water Works Association, 83, 126-131.

Elliott, H., Dempsey, B., \& Maille, P. (1990). Content and fractionation of heavy metals in water treatment sludges. Journal of Environmental Quality, 19, 330-334.

Environment Agency 2013. How to comply with your landspreading permit, 2 edn. Environment Agency.

EPA. (2016). 2015 Annual Effluent Guidelines Review Report. Washington: United States Environmental Protection Agency.

European Commission 2014. 2014/955/EU: Commission Decision of 18 December 2014 amending Decision 2000/532/EC on the list of waste pursuant to Directive 2008/98/EC of the European Parliament and of the Council Text with EEA relevance. In: Commission, E. (ed.).

Gadekar, M. R., \& Ahammed, M. M. (2016). Coagulation/ flocculation process for dye removal using water treatment residuals: modelling through artificial neural networks. Desalination and Water Treatment, 57, 26392-26400.

Gallimore, L., Basta, N., Storm, D., Payton, M., Huhnke, R., \& Smolen, M. (1999). Water treatment residual to reduce nutrients in surface runoff from agricultural land. Journal of Environmental Quality, 28, 1474-1478.

Garau, G., Silvetti, M., Castaldi, P., Mele, E., Deiana, P., \& Deiana, S. (2014). Stabilising metal (loid) $\mathrm{s}$ in soil with iron and aluminium-based products: microbial, biochemical and plant growth impact. Journal of Environmental Management, 139, 146-153.

Geertsema, W. S., Knocke, W. R., Novak, J. T., \& Dove, D. (1994). Long-term effects of sludge application to land. Journal - American Water Works Association, 86, 64-74.

George, D., Berk, S., Adams, V., Morgan, E., Roberts, R., Holloway, C., Craig Lott, R., Holt, L., Ting, R., Welch, A. (1991). Alum sludge in the aquatic environment. In Alum sludge in the aquatic environment. AWWAR.

George, D., Berk, S., Adams, V., Ting, R., Roberts, R., Parks, L., \& Lott, R. (1995). Toxicity of alum sludge extracts to a freshwater alga, protozoan, fish, and marine bacterium. 
Archives of Environmental Contamination and Toxicology, 29, 149-158.

Gibbons, M. K., \& Gagnon, G. A. (2010). Adsorption of arsenic from a Nova Scotia groundwater onto water treatment residual solids. Water Research, 44, 5740-5749.

Gibbons, M. K., \& Gagnon, G. A. (2011). Understanding removal of phosphate or arsenate onto water treatment residual solids. Journal of Hazardous Materials, 186, 1916-1923.

Gibbons, M. K., Mortula, M. M., \& Gagnon, G. A. (2009). Phosphorus adsorption on water treatment residual solids. Journal of Water Supply: Research and Technology-AQUA, $58,1-10$.

Golbold, P., Lewin, K., Graham, A., \& Barker, P. (2003). The potential reuse of water utility products as secondary commercial materials. Swindon: Water Research Council.

Gon Kim, J., Hyun Kim, J., Moon, H.-S., Chon, C.-M., \& Sung Ahn, J. (2002). Removal capacity of water plant alum sludge for phosphorus in aqueous solutions. Chemical Speciation and Bioavailability, 14, 67-73.

Gruninger, R. M. (1975). Disposal of waste alum sludge from water treatment plants. Journal - Water Pollution Control Federation, 543-552.

Hall, W. S., \& Hall, L. W. (1989). Toxicity of alum sludge to Ceriodaphnia dubia and Pimephales promelas. Bulletin of Environmental Contamination and Toxicology, 42, 791-798.

Hegazy, B., Fouad, H. A., \& Hassanain, A. M. (2012). Brick manufacturing from water treatment sludge and rice husk ash. Australian Journal of Basic and Applied Sciences, 6, 453-461.

Heil, D., \& Barbarick, K. (1989). Water treatment sludge influence on the growth of sorghum-sudangrass. Journal of Environmental Quality, 18, 292-298.

Herrmann, J., \& Frick, K. (1995). Do stream invertebrates accumulate aluminium at low $\mathrm{pH}$ conditions? Water, Air, \& Soil Pollution, 85, 407-412.

Hidalgo, A., Murcia, M., Gomez, M., Gomez, E., GarciaIzquierdo, C., \& Solano, C. (2016). Possible uses for sludge from drinking water treatment plants. Journal of Environmental Engineering, 143, 04016088.

HM Revenue \& Customs. 2018. Rates and allowances for Landfill Tax [Online]. Available: https://www.gov. uk/government/publications/rates-and-allowances-landfilltax/landfill-tax-rates-from-1-april-2013 [Accessed 01/10/18].

Hovsepyan, A., \& Bonzongo, J.-C. J. (2009). Aluminum drinking water treatment residuals (Al-WTRs) as sorbent for mercury: implications for soil remediation. Journal of Hazardous Materials, 164, 73-80.

Howells, A. P., Lewis, S. J., Beard, D. B., \& Oliver, I. W. (2018). Water treatment residuals as soil amendments: examining element extractability, soil porewater concentrations and effects on earthworm behaviour and survival. Ecotoxicology and Environmental Safety, 162, 334-340.

Hu, Z., \& Gao, S. (2008). Upper crustal abundances of trace elements: a revision and update. Chemical Geology, 253, 205-221.

Hu, Y., Zhao, Y., Zhao, X., \& Kumar, J. (2012). Comprehensive analysis of step-feeding strategy to enhance biological nitrogen removal in alum sludge-based tidal flow constructed wetlands. Bioresource Technology, 111, 27-35.

Huang, C., Pan, J. R., \& Liu, Y. (2005). Mixing water treatment residual with excavation waste soil in brick and artificial aggregate making. Journal of Environmental Engineering, 131, 272-277.

Ibrahim, M. M., Mahmoud, E. K., \& Ibrahim, D. A. (2015). Effects of vermicompost and water treatment residuals on soil physical properties and wheat yield. International Agrophysics, 29, 157-164.

Ippolito, J. (2015). Aluminum-based water treatment residual use in a constructed wetland for capturing urban runoff phosphorus: column study. Water, Air, \& Soil Pollution, 226, 334.

Ippolito, J., Barbarick, K., Heil, D., Chandler, J., \& Redente, E. (2003). Phosphorus retention mechanisms of a water treatment residual. Journal of Environmental Quality, 32, 18571864.

Ippolito, J., Barbarick, K., Stromberger, M., Paschke, M., \& Brobst, R. (2009a). Water treatment residuals and biosolids long-term co-applications effects to semi-arid grassland soils and vegetation. Soil Science Society of America Journal, 73, 1880-1889.

Ippolito, J. A., Scheckel, K. G., \& Barbarick, K. A. (2009b). Selenium adsorption to aluminum-based water treatment residuals. Journal of Colloid and Interface Science, 338, 4855 .

Ippolito, J. A., Barbarick, K. A., \& Elliott, H. A. (2011). Drinking water treatment residuals: a review of recent uses. Journal of Environmental Quality, 40, 1-12.

Jiao, J., Zhao, J., \& Pei, Y. (2017). Adsorption of Co (II) from aqueous solutions by water treatment residuals. Journal of Environmental Sciences, 52, 232-239.

Kaggwa, R. C., Mulalelo, C. I., Denny, P., \& Okurut, T. O. (2001). The impact of alum discharges on a natural tropical wetland in Uganda. Water Research, 35, 795-807.

Kaosol, T. (2010). Reuse water treatment sludge for hollow concrete block manufacture. Energy Research Journal, 1, 131134.

Keeley, J., Jarvis, P., \& Judd, S. J. (2014). Coagulant recovery from water treatment residuals: a review of applicable technologies. Critical Reviews in Environmental Science and Technology, 44, 2675-2719.

Kim, Y.-S., Kim, D.-H., Yang, J.-S., \& Baek, K. (2012). Adsorption characteristics of As (III) and As (V) on alum sludge from water purification facilities. Separation Science and Technology, 47, 2211-2217.

Kizinievič, O., Kizinievič, V. (2017). Utilisation of drinking water treatment sludge for the manufacturing of ceramic products. In IOP Conference Series: Materials Science and Engineering. IOP Publishing, p 012018.

Kizinievič, O., Žurauskiene, R., Kizinievič, V., \& Žurauskas, R. (2013). Utilisation of sludge waste from water treatment for ceramic products. Construction and Building Materials, 41, 464-473.

Krewski, D., Yokel, R. A., Nieboer, E., Borchelt, D., Cohen, J., Harry, J., Kacew, S., Lindsay, J., Mahfouz, A. M., \& Rondeau, V. (2007). Human health risk assessment for aluminium, aluminium oxide, and aluminium hydroxide. Journal of toxicology and environmental health. Part B, Critical reviews, 10, 1-269.

Lee, Y.-C., Lo, S.-L., Kuo, J., \& Tsai, C.-C. (2012). Beneficial uses of sludge from water purification plants in concrete mix. Environmental Engineering Science, 29, 284-289. 
Lin, S. D., Green, C. D. 1987. A study of wastes from the Centralia water treatment plant and their impact on Crooked Creek. Illinois State Water Survey.

Liu, R., Zhao, Y., Sibille, C., \& Ren, B. (2016). Evaluation of natural organic matter release from alum sludge reuse in wastewater treatment and its role in $\mathrm{P}$ adsorption. Chemical Engineering Journal, 302, 120-127.

Liu, R., Zhao, Y., Zhao, J., Xu, L., \& Sibille, C. (2017). Embedding constructed wetland in sequencing batch reactor for enhancing nutrients removal: a comparative evaluation. Journal of Environmental Management, 192, 302-308.

Lombi, E., Stevens, D., \& McLaughlin, M. (2010). Effect of water treatment residuals on soil phosphorus, copper and aluminium availability and toxicity. Environmental Pollution, 158, 2110-2116.

Lucas, J. B., Dillaha, T. A., Reneau, R. B., Novak, J. T., \& Knocke, W. R. (1994). Alum sludge land application and its effect on plant growth. Journal - American Water Works Association, $86,75-83$.

Madison, R., McDowell, L., O'Connor, G., Wilkinson, N., Davis, P., Adesogan, A. T., Felix, T. L., \& Brennan, M. (2009). Effects of aluminum from water-treatment-residual applications to pastures on mineral status of grazing cattle and mineral concentrations of forages. Communications in Soil Science and Plant Analysis, 40, 3077-3103.

Mahdy, A., Elkhatib, E., Fathi, N., \& Lin, Z.-Q. (2009). Effects of co-application of biosolids and water treatment residuals on corn growth and bioavailable phosphorus and aluminum in alkaline soils in Egypt. Journal of Environmental Quality, 38, 1501-1510.

Mahdy, A., Elkhatib, E., Balba, A., \& Ahmed, G. (2017). Speciation and fractionation of phosphorus in biosolidsamended soils: effects of water treatment residual nanoparticles. International journal of Environmental Science and Technology, 14, 1729-1738.

Makris, K. C., El-Shall, H., Harris, W. G., O'Connor, G. A., \& Obreza, T. A. (2004a). Intraparticle phosphorus diffusion in a drinking water treatment residual at room temperature. Journal of Colloid and Interface Science, 277, 417-423.

Makris, K. C., Harris, W. G., O'Connor, G. A., \& Obreza, T. A. (2004b). Phosphorus immobilization in micropores of drinking-water treatment residuals: implications for longterm stability. Environmental Science \& Technology, 38, 6590-6596.

Makris, K. C., Sarkar, D., \& Datta, R. (2006). Evaluating a drinking-water waste by-product as a novel sorbent for arsenic. Chemosphere, 64, 730-741.

Makris, K. C., Sarkar, D., Parsons, J. G., Datta, R., \& GardeaTorresdey, J. L. (2007). Surface arsenic speciation of a drinking-water treatment residual using X-ray absorption spectroscopy. Journal of Colloid and Interface Science, $311,544-550$.

Makris, K. C., Salazar, J., Quazi, S., Andra, S. S., Sarkar, D., Bach, S. B., \& Datta, R. (2008). Controlling the fate of roxarsone and inorganic arsenic in poultry litter. Journal of Environmental Quality, 37, 963-971.

Makris, K. C., Sarkar, D., Parsons, J. G., Datta, R., \& GardeaTorresdey, J. L. (2009). X-ray absorption spectroscopy as a tool investigating arsenic (III) and arsenic (V) sorption by an aluminum-based drinking-water treatment residual. Journal of Hazardous Materials, 171, 980-986.
Maqbool, N., Khan, Z., \& Asghar, A. (2016). Reuse of alum sludge for phosphorus removal from municipal wastewater. Desalination and Water Treatment, 57, 13246-13254.

Matilainen, A., Vepsäläinen, M., \& Sillanpää, M. (2010). Natural organic matter removal by coagulation during drinking water treatment: a review. Advances in Colloid and Interface Science, 159, 189-197.

Maurice, D., Lightsey, S., Hamrick, E., \& Cox, J. (1998). Alum sludge and zeolite as components of broiler litter. Journal of Applied Poultry Research, 7, 263-267.

McBride, M. B. (1995). Toxic metal accumulation from agricultural use of sludge: are USEPA regulations protective? Journal of Environmental Quality, 24, 5-18.

McGrath, D., Poole, D., Fleming, G., Sinnott, J. 1982. Soil ingestion by grazing sheep. Irish journal of agricultural research, 135-145.

Meis, S., Spears, B. M., Maberly, S. C., O’Malley, M. B., \& Perkins, R. G. (2012). Sediment amendment with Phoslock $₫$ in Clatto Reservoir (Dundee, UK): investigating changes in sediment elemental composition and phosphorus fractionation. Journal of Environmental Management, 93, 185-193.

Miyanoshita, T., Oda, N., Fujiwara, M., \& Furumai, H. (2009). Economic evaluation of combined treatment for sludge from drinking water and sewage treatment plants in Japan. Journal of Water Supply: Research and Technology-AQUA, 58, 221227.

Moghaddam, S. S., Moghaddam, M. A., \& Arami, M. (2010). Coagulation/flocculation process for dye removal using sludge from water treatment plant: optimization through response surface methodology. Journal of Hazardous Materials, 175, 651-657.

Mukherjee, A., Lal, R., \& Zimmerman, A. R. (2014). Impacts of 1.5-year field aging on biochar, humic acid, and water treatment residual amended soil. Soil Science, 179, 333-339.

Nagar, R., Sarkar, D., Makris, K. C., \& Datta, R. (2010). Effect of solution chemistry on arsenic sorption by Fe-and Al-based drinking-water treatment residuals. Chemosphere, 78, 10281035.

Nagar, R., Sarkar, D., Makris, K., \& Datta, R. (2013). Inorganic arsenic sorption by drinking-water treatment residualamended sandy soil: effect of soil solution chemistry. International journal of Environmental Science and Technology, 10, 1-10.

Nagar, R., Sarkar, D., Punamiya, P., \& Datta, R. (2015). Drinking water treatment residual amendment lowers inorganic arsenic bioaccessibility in contaminated soils: a long-term study. Water, Air, Soil Pollut, 226, 366.

O'Kelly, B. C. (2008). Geotechnical properties of a municipal water treatment sludge incorporating a coagulant. Canadian Geotechnical Journal, 45, 715-725.

O'kelly, B. C. (2010). Landfill disposal of alum water treatment residues: some pertinent geoengineering properties. Journal of Residuals Science and Technology, 7.

Ociński, D., Jacukowicz-Sobala, I., \& Kociołek-Balawejder, E. (2016a). Alginate beads containing water treatment residuals for arsenic removal from water-formation and adsorption studies. Environmental Science and Pollution Research, 23, 24527-24539.

Ociński, D., Jacukowicz-Sobala, I., Mazur, P., Raczyk, J., \& Kociołek-Balawejder, E. (2016b). Water treatment residuals 
containing iron and manganese oxides for arsenic removal from water-characterization of physicochemical properties and adsorption studies. Chemical Engineering Journal, 294, 210-221.

Okuda, T., Nishijima, W., Sugimoto, M., Saka, N., Nakai, S., Tanabe, K., Ito, J., Takenaka, K., \& Okada, M. (2014). Removal of coagulant aluminum from water treatment residuals by acid. Water Research, 60, 75-81.

Oladeji, O. O., O'Connor, G. A., Sartain, J. B., \& Nair, V. D. (2007). Controlled application rate of water treatment residual for agronomic and environmental benefits. Journal of Environmental Quality, 36, 1715-1724.

Oladeji, O. O., O’Connor, G. A., \& Brinton, S. R. (2008). Surface applied water treatment residuals affect bioavailable phosphorus losses in Florida sands. Journal of Environmental Management, 88, 1593-1600.

Oliver, I. W., Grant, C. D., \& Murray, R. S. (2011). Assessing effects of aerobic and anaerobic conditions on phosphorus sorption and retention capacity of water treatment residuals. Journal of Environmental Management, 92, 960-966.

Owaid, H. M., Hamid, R. B., \& Taha, M. R. (2017). Variation of ultrasonic pulse velocity of multiple-blended binders concretes incorporating thermally activated alum sludge ash. KSCE Journal of Civil Engineering, 21, 1235-1246.

Park, S. G., Yahata, H., Kurosawa, K., \& Shin, H. T. (2010). Physical and chemical properties of water treatment residue and the characteristics of red pepper growth by using it. Journal of the Faculty of Agriculture, Kyushu University, $55,117-122$.

Parks, J. L., Novak, J., Macphee, M., Itle, C., \& Edwards, M. (2003). Effect of $\mathrm{Ca}$ on As release from ferric and alum residuals. Journal - American Water Works Association, 95, $108-118$

Pecku, S., Hunter, C., \& Hughes, J. (2006). The effects of water treatment residues on soil respiration and microbial community structure. Water Science and Technology, 54, 215-225.

Punamiya, P., Sarkar, D., Rakshit, S., \& Datta, R. (2015). Effect of solution properties, competing ligands, and complexing metal on sorption of tetracyclines on Al-based drinking water treatment residuals. Environmental Science and Pollution Research, 22, 7508-7518.

Punamiya, P., Sarkar, D., Rakshit, S., Elzinga, E. J., \& Datta, R. (2016). Immobilization of tetracyclines in manure and manure-amended soils using aluminum-based drinking water treatment residuals. Environmental Science and Pollution Research, 23, 3322-3332.

Putra, R. S., \& Tanaka, S. (2011). Aluminum drinking water treatment residuals (Al-WTRs) as an entrapping zone for lead in soil by electrokinetic remediation. Separation and Purification Technology, 79, 208-215.

Ramadan, M. O., Fouad, H. A., \& Hassanain, A. M. (2008). Reuse of water treatment plant sludge in brick manufacturing. Journal of Applied Sciences Research (Ma'an, Jordan), 4, 1223-1229.

Razali, M., Zhao, Y., \& Bruen, M. (2007). Effectiveness of a drinking-water treatment sludge in removing different phosphorus species from aqueous solution. Separation and Purification Technology, 55, 300-306.

Rigby, H., Pritchard, D., Collins, D., Walton, K., \& Penney, N. (2013). The use of alum sludge to improve cereal production on a nutrient-deficient soil. Environmental Technology, 34, $1359-1368$.

Rodríguez, N. H., Ramírez, S. M., Varela, M. B., Guillem, M., Puig, J., Larrotcha, E., \& Flores, J. (2010). Re-use of drinking water treatment plant (DWTP) sludge: characterization and technological behaviour of cement mortars with atomized sludge additions. Cement and Concrete Research, 40, 778 786.

Sales, A., de Souza, F. R., \& Almeida, F. D. C. R. (2011). Mechanical properties of concrete produced with a composite of water treatment sludge and sawdust. Construction and Building Materials, 25, 2793-2798.

Santos, P., Martins, C., \& Júlio, E. (2015). Enhancement of the thermal performance of perforated clay brick walls through the addition of industrial nano-crystalline aluminium sludge. Construction and Building Materials, 101, 227-238.

Shamsudin, S.-M., Shahidan, S., Azmi, M., Ghaffar, S., Ghani, M. A., Bahari, N. S., Zuki, S. (2017). The effect of sludge water treatment plant residuals on the properties of compressed brick. In IOP Conference Series: Materials Science and Engineering. IOP Publishing, p 012052.

Silveira, M. L., Driscoll, J. L., Silveira, C. P., Graetz, D. A., Sollenberger, L. E., \& Vendramini, J. (2013). Land application of aluminum water treatment residual to Bahiagrass pastures: soil and forage responses. Agronomy Journal, 105, 796-802.

Silvetti, M., Castaldi, P., Garau, G., Demurtas, D., \& Deiana, S. (2015). Sorption of cadmium (II) and zinc (II) from aqueous solution by water treatment residuals at different $\mathrm{pH}$ values. Water, Air, \& Soil Pollution, 226, 313.

Simpson, A., Burgess, P., \& Coleman, S. (2002). The management of potable water treatment sludge: present situation in the UK. Water Environment Journal, 16, 260-263.

Soleimanifar, H., Deng, Y., Wu, L., \& Sarkar, D. (2016). Water treatment residual (WTR)-coated wood mulch for alleviation of toxic metals and phosphorus from polluted urban stormwater runoff. Chemosphere, 154, 289-292.

Sujana, M., Thakur, R., \& Rao, S. (1998). Removal of fluoride from aqueous solution by using alum sludge. Journal of Colloid and Interface Science, 206, 94-101.

Suman, A., Ahmad, T., Ahmad, K. (2017). Dairy wastewater treatment using water treatment sludge as coagulant: a novel treatment approach. Environment, Development and Sustainability, 1-11.

Sydney Water (2011). Sydney Water Operating Licence Environment Report.

Takashima, M., Nakamura, S., Takano, M., \& Ikemoto, R. (2015). Treatment of eutrophic lake water and phosphorus recovery by reusing alum sludge and/or wood. Journal of Water Reuse and Desalination, 5, 446-453.

Tay, D. Y. Y., Fujinuma, R., \& Wendling, L. A. (2017). Drinking water treatment residual use in urban soils: balancing metal immobilization and phosphorus availability. Geoderma, 305, 113-121.

Teixeira, S., Santos, G., Souza, A., Alessio, P., Souza, S., \& Souza, N. (2011). The effect of incorporation of a Brazilian water treatment plant sludge on the properties of ceramic materials. Applied Clay Science, 53, 561-565.

Tessier, A., Campbell, P. G., \& Bisson, M. (1979). Sequential extraction procedure for the speciation of particulate trace metals. Analytical Chemistry, 51, 844-851. 
Ulén, B., Etana, A., \& Lindström, B. (2012). Effects of aluminium water treatment residuals, used as a soil amendment to control phosphorus mobility in agricultural soils. Water Science and Technology, 65, 1903-1911.

USEPA (2011). Drinking water treatment plant residuals management technical report.

Vaezi, F., \& Batebi, F. (2001). Recovery of iron coagulants from Tehran water-treatment-plant sludge for reusing in textile wastewater treatment. Iranian Journal of Public Health, 30, 135-138.

Van Alstyne, R., McDowell, L., Davis, P., Wilkinson, N., \& O'Connor, G. (2007). Effects of an aluminum-water treatment residual on performance and mineral status of feeder lambs. Small Ruminant Research, 73, 77-86.

Vicenzi, J., Bernardes, A. M., \& Bergmann, C. P. (2005). Evaluation of alum sludge as raw material for ceramic products. Industrial Ceramics, 25, 7-16.

Waite, T. O., Dharmappa, H. B. (1993). Optimal management of water treatment plant residuals: technical and commercial review. Sydney, Australia.

Walsh, M. (2009). Data review from full-scale installations for water treatment plant residuals treatment processes. Halifax: American Water Works Association.

Wang, C., \& Pei, Y. (2013). A comparison of the phosphorus immobilization capabilities of water treatment residuals before and after settling from lake water. Separation and Purification Technology, 117, 83-88.

Wang, K.-S., Chiang, K.-Y., Perng, J.-K., \& Sun, C.-J. (1998). The characteristics study on sintering of municipal solid waste incinerator ashes. Journal of Hazardous Materials, 59, 201210.

Wang, C., Qi, Y., \& Pei, Y. (2012a). Laboratory investigation of phosphorus immobilization in lake sediments using water treatment residuals. Chemical Engineering Journal, 209, 379-385.

Wang, C., Zhao, Y., \& Pei, Y. (2012b). Investigation on reusing water treatment residuals to remedy soil contaminated with multiple metals in Baiyin, China. Journal of Hazardous Materials, 237, 240-246.

Wang, C., Gao, S., Pei, Y., \& Zhao, Y. (2013a). Use of drinking water treatment residuals to control the internal phosphorus loading from lake sediments: laboratory scale investigation. Chemical Engineering Journal, 225, 93-99.

Wang, C., Liang, J., Pei, Y., \& Wendling, L. A. (2013b). A method for determining the treatment dosage of drinking water treatment residuals for effective phosphorus immobilization in sediments. Ecological Engineering, 60, 421-427.

Wang, C., Bai, L., Pei, Y., \& Wendling, L. A. (2014). Comparison of metals extractability from $\mathrm{Al} / \mathrm{Fe}$-based drinking water treatment residuals. Environmental Science and Pollution Research, 21, 13528-13538.

Wang, W., Ma, C., Zhang, Y., Yang, S., Shao, Y., \& Wang, X. (2016). Phosphate adsorption performance of a novel filter substrate made from drinking water treatment residuals. Journal of Environmental Sciences, 45, 191-199.

Wang, H.-Q., Zhang, L.-Y., Fang, X.-M., \& Zhang, A.-N. (2017a). Modified water treatment residual as flocculant for Microcystis aeruginosa removal and water purification. International journal of Environmental Science and Technology, 14, 2543-2550.
Wang, W., Han, Y., Liu, H., Zhang, K., Yue, Q., Bo, L., \& Wang, X. (2017b). Pollutant removal performance of an integrated upflow-constructed wetland filled with haydites made of Albased drinking water treatment residuals. Environmental Technology, 38, 1111-1119.

WHO 2017. Guidelines for drinking-water quality: first addendum to the fourth edition.

Würzer, M., Wiedenmann, A., \& Botzenhart, K. (1995). Microbiological quality of residues from drinking water preparation. Water Science and Technology, 31, 75.

Xu, G., Yan, Z., Wang, Y., \& Wang, N. (2009). Recycle of alum recovered from water treatment sludge in chemically enhanced primary treatment. Journal of Hazardous Materials, 161, 663-669.

Xu, L., Zhao, Y., Doherty, L., Hu, Y., \& Hao, X. (2016a). Promoting the bio-cathode formation of a constructed wetland-microbial fuel cell by using powder activated carbon modified alum sludge in anode chamber. Scientific Reports, 6.

Xu, Y., Chen, T., Xu, R., He, L., \& Cui, F. (2016b). Impact of recycling alum sludge on coagulation of low-turbidity source waters. Desalination and Water Treatment, 57, 6732-6739.

Xu, H., Pei, H., Jin, Y., Ma, C., Wang, Y., Sun, J., \& Li, H. (2018). High-throughput sequencing reveals microbial communities in drinking water treatment sludge from six geographically distributed plants, including potentially toxic cyanobacteria and pathogens. The Science of the Total Environment, 634, 769-779.

Yang, Y., Tomlinson, D., Kennedy, S., \& Zhao, Y. (2006a). Dewatered alum sludge: A potential adsorbent for phosphorus removal. Water Science and Technology, 54, 207-213.

Yang, Y., Zhao, Y., Babatunde, A., Wang, L., Ren, Y., \& Han, Y. (2006b). Characteristics and mechanisms of phosphate adsorption on dewatered alum sludge. Separation and Purification Technology, 51, 193-200.

Yen, C.-L., Tseng, D.-H., \& Lin, T.-T. (2011). Characterization of eco-cement paste produced from waste sludges. Chemosphere, 84, 220-226.

Young, T. C., Collins, A. G., \& Armstrong, R. A. (1988). A pilotscale evaluation of alum treatments to reduce lake sediment phosphorus release. Journal of Environmental Quality, 17, 673-676.

Yuan, N., Wang, C., \& Pei, Y. (2016a). Investigation on the ecotoxicity of lake sediments with the addition of drinking water treatment residuals. Journal of Environmental Sciences, 46, $5-15$.

Yuan, N., Wang, C., Pei, Y., \& Jiang, H. (2016b). Applicability of drinking water treatment residue for lake restoration in relation to metal/metalloid risk assessment. Scientific Reports, 6, 38638 .

Yusuff, S., Ong, K., Yunus, W. Z. W., Fitrianto, A., \& Ahmad, M. (2017). Removal of methylene blue from aqueous solutions using alum sludge: sorption optimization by response surface methodology. Journal of Fundamental and Applied Sciences, 9, 532-545.

Zhao, Y., \& Yang, Y. (2010). Extending the use of dewatered alum sludge as a P-trapping material in effluent purification: study on two separate water treatment sludges. Journal of Environmental Science and Health, Part A, 45, 1234-1239.

Zhao, Y., Zhao, X., \& Babatunde, A. (2009). Use of dewatered alum sludge as main substrate in treatment reed bed receiving 
agricultural wastewater: long-term trial. Bioresource Technology, 100, 644-648.

Zhao, Y., Babatunde, A., Hu, Y., Kumar, J., \& Zhao, X. (2011). Pilot field-scale demonstration of a novel alum sludge-based constructed wetland system for enhanced wastewater treatment. Process Biochemistry, 46, 278-283.

Zhao, X., Zhao, Y., \& Kearney, P. (2013a). Phosphorus recovery as AlPO 4 from beneficially reused aluminium sludge arising from water treatment. Environmental Technology, 34, 263268.

Zhao, Y., Collum, S., Phelan, M., Goodbody, T., Doherty, L., \& $\mathrm{Hu}$, Y. (2013b). Preliminary investigation of constructed wetland incorporating microbial fuel cell: batch and continuous flow trials. Chemical Engineering Journal, 229, 364 370.

Zhao, X., Zhao, Y., Wang, W., Yang, Y., Babatunde, A., Hu, Y., \& Kumar, L. (2015). Key issues to consider when using alum sludge as substrate in constructed wetland. Water Science and Technology, 71, 1775-1782.

Zhao, Y., Liu, R., Awe, O. W., Yang, Y., \& Shen, C. (2018). Acceptability of land application of alum-based water treatment residuals-an explicit and comprehensive review. Chemical Engineering Journal.

Zhou, Y.-F., \& Haynes, R. J. (2011). Removal of Pb (II), Cr (III) and $\mathrm{Cr}$ (VI) from aqueous solutions using alum-derived water treatment sludge. Water, Air, \& Soil Pollution, 215, 631-643.

Zohar, I., Ippolito, J. A., Massey, M. S., \& Litaor, I. M. (2017). Innovative approach for recycling phosphorous from agrowastewaters using water treatment residuals (WTR). Chemosphere, 168, 234-243.

Publisher's Note Springer Nature remains neutral with regard to jurisdictional claims in published maps and institutional affiliations. 